\title{
Preliminary assessment of the scope and scale of illegal killing and taking of birds in the Mediterranean
}

\author{
ANNE-LAURE BROCHET, WILLEM VAN DEN BOSSCHE, \\ SHARIF JBOUR, P. KARIUKI NDANG'ANG'A, VICTORIA R. JONES, \\ WED ABDEL LATIF IBRAHIM ABDOU, ABDEL RAZZAQ AL- HMOUD, \\ NABEGH GHAZAL ASSWAD, JUAN CARLOS ATIENZA, IMAD ATRASH, \\ NICHOLAS BARBARA, KEITH BENSUSAN, TAULANT BINO, \\ CLAUDIO CELADA, SIDI IMAD CHERKAOUI, JULIETA COSTA, \\ BERNARD DECEUNINCK, KHALED SALEM ETAYEB, \\ CLAUDIA FELTRUP-AZAFZAF, JERNEJ FIGELJ, MARCO GUSTIN, \\ PRIMOŽ KMECL, VLADO KOCEVSKI, MALAMO KORBETI, \\ DRAŽEN KOTROŠAN, JUAN MULA LAGUNA, MATTEO LATTUADA, \\ DOMINGOS LEITÃO, PAULA LOPES, NICOLÁS LÓPEZ-JIMÉNEZ, \\ VEDRAN LUCIĆ, THIERRY MICOL, AÏSSA MOALI, YOAV PERLMAN, \\ NICOLA PILUDU, DANAE PORTOLOU, KSENIJA PUTILIN, \\ GWENAEL QUAINTENNE, GHASSAN RAMADAN-JARADI, MILAN RUŽIĆ, \\ ANNA SANDOR, NERMINA SARAJLI, DARKO SAVELJIĆ, \\ ROBERT D. SHELDON, TASSOS SHIALIS, NIKOS TSIOPELAS, FRAN VARGAS, \\ CLAIRE THOMPSON, ARIEL BRUNNER, RICHARD GRIMMETT and \\ STUART H.M. BUTCHART
}

\section{Summary}

Illegal killing/taking of birds is a growing concern across the Mediterranean. However, there are few quantitative data on the species and countries involved. We assessed numbers of individual birds of each species killed/taken illegally in each Mediterranean country per year, using a diverse range of data sources and incorporating expert knowledge. We estimated that $11-36$ million individuals per year may be killed/taken illegally in the region, many of them on migration. In each of Cyprus, Egypt, Italy, Lebanon and Syria, more than two million birds may be killed/taken on average each year. For species such as Blackcap Sylvia atricapilla, Common Quail Coturnix coturnix, Eurasian Chaffinch Fringilla coelebs, House Sparrow Passer domesticus and Song Thrush Turdus philomelos, more than one million individuals of each species are estimated to be killed/ taken illegally on average every year. Several species of global conservation concern are also reported to be killed/taken illegally in substantial numbers: Eurasian Curlew Numenius arquata, Ferruginous Duck Aythya nyroca and Rock Partridge Alectoris graeca. Birds in the Mediterranean are illegally killed/taken primarily for food, sport and for use as cage-birds or decoys. At the 20 worst locations with the highest reported numbers, 7.9 million individuals may be illegally killed/ taken per year, representing $34 \%$ of the mean estimated annual regional total number of birds illegally killed/taken for all species combined. Our study highlighted the paucity of data on illegal killing/taking of birds. Monitoring schemes which use systematic sampling protocols are needed 
to generate increasingly robust data on trends in illegal killing/taking over time and help stakeholders prioritise conservation actions to address this international conservation problem. Large numbers of birds are also hunted legally in the region, but specific totals are generally unavailable. Such data, in combination with improved estimates for illegal killing/taking, are needed for robustly assessing the sustainability of exploitation of birds.

\section{Introduction}

Illegal activities, such as poaching and poisoning of wild animals, are common worldwide and threaten biological diversity in many terrestrial and aquatic ecosystems (Gavin et al. 2010, St. John et al. 2010). Overexploitation is one of the main drivers of bird extinctions globally (BirdLife International 2013), and is the second most significant threat (after habitat loss/ degradation, driven primarily by unsustainable agriculture) to migratory birds (Kirby et al. 2008). Birds are taken for use as pets or display ( $37 \%$ of all bird species), or hunted for food $(14 \%)$ and sport (4\%) (Butchart 2008), with much unsustainable use being illegal (BirdLife International 2013).

The illegal killing and taking of birds is known to be a particular and growing concern across the Mediterranean region (e.g. Franzen 2010, Schneider-Jacoby and Spangenberg 2010, BirdLife International 2011, CABS 2014, Emile et al. 2014). The first region-wide review of the killing of migratory birds was published in 1979 by ICBP (now BirdLife International), and estimated that hundreds of millions of migratory birds were killed each year in the Mediterranean (Woldhek 1979), mainly based on the number of hunters per country, but without distinguishing between legal hunting and illegal killing. Subsequently, Magnin (1991) estimated that 1,000 million migratory birds were illegally shot and trapped every year in Mediterranean countries, including some 100,000 raptors and "probably many millions" of individuals of protected species or of huntable species killed illegally. Again these totals were mainly extrapolated from estimated numbers of people shooting birds (9-10 million) or trapping them ( 1 million) and anecdotal numbers of traps and shots fired in areas known to have a high level of illegal killing and trapping (e.g. Malta, Cyprus and Turkey). More recently, Schneider-Jacoby and Spangenberg (2010) and CABS (2014) also reported that "millions" of birds are illegally killed in Mediterranean countries. Illegal killing and taking of birds occurs not only in North Africa and the Middle East (BirdLife International 2007), but is also widespread in Europe, including European Union (EU) countries, despite national and EU legislation and commitments under international conventions (BirdLife International 2011).

These studies have increased our understanding of the breadth and potential scope and scale of illegal activities taking place across the Mediterranean region and provide useful qualitative information, but there is little robust quantitative information on the identity of the species involved, total numbers of individual birds affected, impacts on bird populations, trends over time, the most significant illegal activities, the most significant motivations for illegal killing and taking, or the geographical variation among all of these. While some quantitative data are available for some Mediterranean countries: e.g. Raine (2007) for Malta, BirdLife Cyprus (2015a) for Cyprus, Mikuška et al. (2014) for parts of Croatia, Murgui (2014) for parts of Spain, such data are lacking from others, and so the region-wide picture is still obscure.

Recognising that illegal killing and taking of birds represent a significant conservation issue, international activity to address this has accelerated in recent years, with the European Commission publishing a 'Roadmap towards eliminating illegal killing, trapping and trade of birds' (European Commission 2012), the Bern Convention developing the 'Tunis Action Plan for the eradication of illegal killing, trapping and trade of wild birds' (Council of Europe 2013), and the Convention on the Conservation of Migratory Species of Wild Animals adopting a Resolution in 2014 and establishing an 'Intergovernmental Task Force to address illegal killing, taking and trade of migratory birds in the Mediterranean' (UNEP/CMS 2014). However the current lack of information about illegal killing and taking of birds hampers the ability of governments, policy instruments, 
organisations and initiatives to set appropriate priorities and address the issue. Robustly quantifying the scale and scope of the illegal killing and taking of birds and its possible impact on individual species is therefore an urgent priority (Vickery et al. 2014), as well as the sustainability of the harvest of birds (both legal and illegal components) at the flyway scale. To address the former need and provide useful information for priority-setting both across the geographic region and within single-species conservation efforts, we aimed to assess how many individual birds of which species may be killed/taken illegally each year, which species may be the most impacted, what types of illegal activities may be most significant, which reasons for illegal killing and taking may be most important, and which may be the worst locations and countries for the illegal killing and taking of birds in the Mediterranean.

\section{Methods}

\section{Study area and study species}

For this study, 26 Mediterranean and peri-Mediterranean (hereafter Mediterranean) countries/ territories were assessed (see Table I). Owing to the wide distribution of most wild bird species occurring in the region and beyond, we carried out assessments at the national level even if only part of the country/territory assessed is in the Mediterranean area. All native species regularly present (i.e. excluding vagrants) in any season in at least one of the assessed countries were assessed (Table $\mathrm{S}_{1}$ in the online supplementary materials).

\section{Data collection}

For this assessment, we defined illegal killing and taking of birds (hereafter 'illegal killing') as any form of deliberate action that results in the death or removal from the wild of an individual bird (regardless of whether it was the target of this action or not) that is prohibited under national or regional legislation. Examples of illegal killing include hunting of 'game' species during the closed season, use of prohibited methods (e.g. mist-nets, lime-sticks, poisons) or activities (e.g. eggcollecting), killing protected species, and/or inside protected areas in which such activities are forbidden. Species can be killed for different reasons, such as for food, trade or to be used as cage pets. All 26 countries/territories assessed, except Libya, have hunting/taking regulations in their national legislation. This varies from lists of legally huntable species with open and closed seasons (e.g. in EU countries) to complete (permanent or temporary) hunting bans on all species (e.g. in Albania, Algeria, Gibraltar, Lebanon, Palestinian Authority Territories and Syria), thus defining what is illegal at the national level. In case of complete hunting bans, we considered all killing as illegal. In the case of Libya, prior to the recent revolution all hunting of birds was illegal. Currently there is a legislative hiatus, and given this political uncertainty we considered that all current killing of birds as illegal.

Between July 2014 and June 2015, we asked national experts/organisations (identified within the BirdLife partnership) from 26 countries/territories to assess if wild birds were known or likely to be illegally killed in non-trivial numbers in their country. For those for which the answer was 'yes', we asked experts to provide quantitative information, based on their own data, experience and/or knowledge, as well as any available, relevant information (data from publications, grey literature, relevant databases, animal rehabilitation centres, police reports, bird ringing schemes, etc.). We also encouraged them to consult other individuals and organisations who may have relevant information (e.g. government departments, hunting associations, local conservation groups, etc.).

We first asked for each of the assessed species whether it was known or likely to be affected by illegal killing, with response options being: "Yes (or likely)", "Yes but numbers killed are likely to be insignificant", or "No (or unlikely)". We defined 'insignificant' to be when the maximum estimate of the number of birds illegally killed was $\leq 100$ individuals/year for a passerine species 
Table 1. Estimated numbers of individual birds illegally killed/taken per year in each assessed country/territory in the Mediterranean. Values in bold indicate the three countries with the highest numbers in each column (see text).

\begin{tabular}{|c|c|c|c|c|c|c|c|c|}
\hline Country & $\begin{array}{l}\text { No. species } \\
\text { regularly } \\
\text { occurring }\end{array}$ & $\begin{array}{l}\% \text { of species known } \\
\text { or likely to be illegally } \\
\text { killed/taken (values } \\
\text { in parentheses include } \\
\text { species killed/taken in } \\
\text { insignificant numbers) }\end{array}$ & $\begin{array}{l}\text { Mean estimated } \\
\text { no. individual } \\
\text { birds illegally } \\
\text { killed/taken per } \\
\text { year }\end{array}$ & $\begin{array}{l}\text { Mean score for } \\
\text { basis of estimates } \\
\text { ( } 1=\text { informed } \\
\text { expert opinion to } \\
3=\text { extrapolated } \\
\text { from systematic } \\
\text { monitoring) }\end{array}$ & $\begin{array}{l}\text { Mean confidence } \\
\text { in estimates } \\
(1=\text { not at all } \\
\text { confident, } \\
5=\text { extremely } \\
\text { confident) }\end{array}$ & $\begin{array}{l}\text { Mean estimated } \\
\text { trend over the } \\
\text { last 1o years in } \\
\text { illegal killing/taking }\end{array}$ & $\begin{array}{l}\text { Mean estimated } \\
\text { no. individual } \\
\text { birds illegally } \\
\text { killed/taken per } \\
\text { year per } \mathrm{km}^{2}\end{array}$ & $\begin{array}{l}\text { Mean estimated } \\
\text { no. individual } \\
\text { birds illegally } \\
\text { killed/taken } \\
\text { per year per } \\
\text { 1oo capita of } \\
\text { human } \\
\text { population }\end{array}$ \\
\hline & & & $(\min -\max )$ & & & & $(\min -\max )$ & $(\min -\max )$ \\
\hline Albania & 296 & $32(62)$ & $\begin{array}{l}265,000 \\
(206,000-325,000) \\
28,900\end{array}$ & 1.0 & 2.7 & -1.5 & $\begin{array}{l}9.2 \\
(7.2-11.3) \\
0.01\end{array}$ & $\begin{array}{l}8.8 \\
(6.8-10.7) \\
0.1\end{array}$ \\
\hline Algeria & 310 & $6(13)$ & $(17,500-40,300)$ & 1.0 & 1.1 & -1.6 & $(0.01-0.02)$ & $(0.05-0.01)$ \\
\hline $\begin{array}{l}\text { Bosnia and } \\
\text { Herzegovina }\end{array}$ & 274 & $16(40)$ & $\begin{array}{c}34,700 \\
(22,400-46,900) \\
510,000\end{array}$ & 1.0 & 1.0 & Unknown & $\begin{array}{c}0.7 \\
(0.4-0.9) \\
9.0\end{array}$ & $\begin{array}{c}0.9 \\
(0.6-1.2) \\
11.4\end{array}$ \\
\hline Croatia & 306 & $32(45)$ & $\begin{array}{l}(166,000-855,000) \\
2,300,000\end{array}$ & 1.1 & 2.1 & Unknown & $\begin{array}{l}(2.9-15.1) \\
248.3\end{array}$ & $\begin{array}{l}(3 \cdot 7-19.1) \\
195 \cdot 9\end{array}$ \\
\hline Cyprus & 278 & $27(51)$ & $\begin{array}{l}(1,300,000-3,200,000) \\
5,400,000\end{array}$ & 2.5 & 2.8 & +2.0 & $\begin{array}{l}(\mathbf{1} 45.8-350.8) \\
5.4\end{array}$ & $\begin{array}{l}(115.1-276.8) \\
6.3\end{array}$ \\
\hline Egypt & 372 & $27(35)$ & $\begin{array}{l}(302,000-10,600,000) \\
522,000\end{array}$ & 1.5 & 1.6 & -0.4 & $\begin{array}{l}(0.3-10.6) \\
0.9\end{array}$ & $\begin{array}{l}(0.3-12.2) \\
0.8\end{array}$ \\
\hline $\begin{array}{l}\text { France } \\
\text { Gibraltar }\end{array}$ & $\begin{array}{l}349 \\
161\end{array}$ & $\begin{array}{l}32(59) \\
0(0)\end{array}$ & $(149,000-895,000)$ & 1.5 & $\begin{array}{l}1.7 \\
\text { birds killed in non }\end{array}$ & $\begin{array}{l}-0.7 \\
\text { 1-trivial numbers }\end{array}$ & $(0.3-1.6)$ & $(0.2-1.4)$ \\
\hline $\begin{array}{l}\text { Greece } \\
\text { Israel }\end{array}$ & $\begin{array}{l}345 \\
379\end{array}$ & $\begin{array}{c}32(50) \\
0(0)\end{array}$ & $\begin{array}{l}704,000 \\
(485,000-922,000)\end{array}$ & 1.6 & $\begin{array}{l}2.3 \\
\text { birds killed in non }\end{array}$ & $\begin{array}{l}\text {-0.1 } \\
\text { 1-trivial numbers }\end{array}$ & $\begin{array}{l}5 \cdot 3 \\
(3 \cdot 7-7 \cdot 0)\end{array}$ & $\begin{array}{c}6.5 \\
(4 \cdot 5-8.6)\end{array}$ \\
\hline Italy & 348 & $43(66)$ & $\begin{array}{l}5,600,000 \\
(3,400,000-7,800,000) \\
\quad 17,300\end{array}$ & 1.1 & 1.1 & Unknown & $\begin{array}{l}18.6 \\
\left(11.3^{-25 \cdot 9)}\right. \\
0.2\end{array}$ & $\begin{array}{l}9.1 \\
(5 \cdot 5-12.7) \\
0.2\end{array}$ \\
\hline Jordan & 323 & $8(24)$ & $(13,000-21,600)$ & 1.6 & 2.8 & -1.0 & $(0.1-0.2)$ & $(0.2-0.03)$ \\
\hline
\end{tabular}


Table 1 . Continued.

\begin{tabular}{|c|c|c|c|c|c|c|c|c|}
\hline Country & $\begin{array}{l}\text { No. species } \\
\text { regularly } \\
\text { occurring }\end{array}$ & $\begin{array}{l}\text { \% of species known } \\
\text { or likely to be illegally } \\
\text { killed/taken (values } \\
\text { in parentheses include } \\
\text { species killed/taken in } \\
\text { insignificant numbers) }\end{array}$ & $\begin{array}{l}\text { Mean estimated } \\
\text { no. individual } \\
\text { birds illegally } \\
\text { killed/taken per } \\
\text { year }\end{array}$ & $\begin{array}{l}\text { Mean score for } \\
\text { basis of estimates } \\
(1=\text { informed } \\
\text { expert opinion to } \\
3=\text { extrapolated } \\
\text { from systematic } \\
\text { monitoring) }\end{array}$ & $\begin{array}{l}\text { Mean confidence } \\
\text { in estimates } \\
(1=\text { not at all } \\
\text { confident, } \\
5=\text { extremely } \\
\text { confident) }\end{array}$ & $\begin{array}{l}\text { Mean estimated } \\
\text { trend over the } \\
\text { last 1o years in } \\
\text { illegal killing/taking }\end{array}$ & $\begin{array}{l}\text { Mean estimated } \\
\text { no. individual } \\
\text { birds illegally } \\
\text { killed/taken per } \\
\text { year per km² }\end{array}$ & $\begin{array}{l}\text { Mean estimated } \\
\text { no. individual } \\
\text { birds illegally } \\
\text { killed/taken } \\
\text { per year per } \\
\text { Ioo capita of } \\
\text { human } \\
\text { population }\end{array}$ \\
\hline & & & $(\min -\max )$ & & & & $(\min -\max )$ & $(\min -\max )$ \\
\hline Lebanon & 291 & $59(91)$ & $\begin{array}{l}2,600,000 \\
(1,700,000-3,5000,000) \\
503,000\end{array}$ & 1.5 & 2.9 & +0.4 & $\begin{array}{l}248.0 \\
(161.3-334.6) \\
\quad 0.3\end{array}$ & $\begin{array}{l}43.8 \\
(28.5-59.2) \\
8.0\end{array}$ \\
\hline Libya & 265 & $23(25)$ & $\begin{array}{l}(325,000-680,000) \\
2,100\end{array}$ & 1.0 & 4.0 & +2.0 & $\begin{array}{l}(0.2-0.4) \\
0.1\end{array}$ & $\begin{array}{l}(5.2-10.9) \\
0.1\end{array}$ \\
\hline Macedonia FYR & 321 & $3(10)$ & $\begin{array}{c}(600-3,700) \\
108,000\end{array}$ & 1.2 & 1.9 & Unknown & $\begin{array}{l}(0.02-0.1) \\
342.6\end{array}$ & $\begin{array}{l}(0.003-0.2) \\
26.2\end{array}$ \\
\hline Malta & 212 & $26(64)$ & $\begin{array}{l}(5,800-211,000) \\
130,000\end{array}$ & 1.9 & 2.1 & -0.1 & $\begin{array}{l}(18.4-666.7) \\
9.4\end{array}$ & $\begin{array}{l}(1.4-51.1) \\
20.0\end{array}$ \\
\hline Montenegro & 306 & $21(36)$ & $\begin{array}{l}(64,000-197,000) \\
74,400\end{array}$ & 1.5 & 2.6 & -0.4 & $\begin{array}{l}(4.6-14.2) \\
0.2\end{array}$ & $\begin{array}{l}(9.8-30.2) \\
0.2\end{array}$ \\
\hline $\begin{array}{l}\text { Morocco } \\
\text { Palestinian } \\
\text { Authority }\end{array}$ & 331 & $19(29)$ & $\begin{array}{l}(23,400-125,000) \\
89,700\end{array}$ & 1.5 & 2.0 & +0.6 & $\begin{array}{l}(0.1-0.3) \\
14.4\end{array}$ & $\begin{array}{l}(0.1-0.4) \\
2.0\end{array}$ \\
\hline Territories & 263 & $19(38)$ & $\begin{array}{l}(70,000-109,000) \\
82,400\end{array}$ & 1.0 & 2.9 & +0.2 & $\begin{array}{l}(11.3-17.6) \\
0.9\end{array}$ & $\begin{array}{l}(1.5-2.4) \\
\quad 0.8\end{array}$ \\
\hline Portugal & 291 & $20(90)$ & $\begin{array}{l}(32,400-132,000) \\
133,000\end{array}$ & 1.8 & 1.7 & +0.7 & $\begin{array}{c}(0.4-1.4) \\
1.7\end{array}$ & $\begin{array}{c}(0.3-1.2) \\
1.8\end{array}$ \\
\hline Serbia & 302 & $20(74)$ & $\begin{array}{l}(104,000-163,000) \\
8,000\end{array}$ & 1.5 & $3 \cdot 5$ & +0.3 & $\begin{array}{c}(1.3-2.1) \\
0.4\end{array}$ & $\begin{array}{c}(1.4-2.3) \\
0.4\end{array}$ \\
\hline Slovenia & 283 & $9(27)$ & $\begin{array}{l}(200-15,700) \\
254,000\end{array}$ & 1.0 & 1.5 & Unknown & $\begin{array}{l}(0.01-0.8) \\
0.5\end{array}$ & $(0.01-0.8)$ \\
\hline Spain & 376 & $16(45)$ & $(103,000-405,000)$ & 1.9 & 3.2 & -0.2 & $(0.2-0.8)$ & $(0.2-0.8)$ \\
\hline
\end{tabular}


Table 1. Continued.

\begin{tabular}{|c|c|c|c|c|c|c|c|c|}
\hline \multirow[t]{2}{*}{ Country } & \multirow[t]{2}{*}{$\begin{array}{l}\text { No. species } \\
\text { regularly } \\
\text { occurring }\end{array}$} & \multirow[t]{2}{*}{$\begin{array}{l}\% \text { of species known } \\
\text { or likely to be illegally } \\
\text { killed/taken (values } \\
\text { in parentheses include } \\
\text { species killed/taken in } \\
\text { insignificant numbers) }\end{array}$} & $\begin{array}{l}\text { Mean estimated } \\
\text { no. individual } \\
\text { birds illegally } \\
\text { killed/taken per } \\
\text { year }\end{array}$ & \multirow[t]{2}{*}{$\begin{array}{l}\text { Mean score for } \\
\text { basis of estimates } \\
\text { ( } 1=\text { informed } \\
\text { expert opinion to } \\
3=\text { extrapolated } \\
\text { from systematic } \\
\text { monitoring) }\end{array}$} & \multirow[t]{2}{*}{$\begin{array}{l}\text { Mean confidence } \\
\text { in estimates } \\
(1=\text { not at all } \\
\text { confident, } \\
5=\text { extremely } \\
\text { confident })\end{array}$} & \multirow[t]{2}{*}{$\begin{array}{l}\text { Mean estimated } \\
\text { trend over the } \\
\text { last 1o years in } \\
\text { illegal killing/taking }\end{array}$} & $\begin{array}{l}\text { Mean estimated } \\
\text { no. individual } \\
\text { birds illegally } \\
\text { killed/taken per } \\
\text { year per km² }\end{array}$ & $\begin{array}{l}\text { Mean estimated } \\
\text { no. individual } \\
\text { birds illegally } \\
\text { killed/taken } \\
\text { per year per } \\
\text { Ioo capita of } \\
\text { human } \\
\text { population }\end{array}$ \\
\hline & & & $(\min -\max )$ & & & & $(\min -\max )$ & $(\min -\max )$ \\
\hline Syria & 333 & $43(90)$ & $\begin{array}{l}3,900,000 \\
(2,900,000-4,900,000) \\
139,000\end{array}$ & 1.0 & 3.2 & -0.4 & $\begin{array}{l}20.9 \\
(15.6-26.3) \\
\quad 0.8\end{array}$ & $\begin{array}{l}21.6 \\
(16.1-27.2) \\
1.3\end{array}$ \\
\hline Tunisia & 303 & $33(62)$ & $\begin{array}{l}(50,500-227,000) \\
\quad 71,200\end{array}$ & 1.1 & 2.6 & Unknown & $\begin{array}{l}(0.3-1.4) \\
0.1\end{array}$ & $\begin{array}{l}(0.5-2.1) \\
0.1\end{array}$ \\
\hline Turkey & 387 & $21(33)$ & $\begin{array}{l}(25,000-117,300) \\
23,500,000\end{array}$ & 1.3 & 1.6 & Unknown & $\begin{array}{l}(0.03-0.1) \\
2.7\end{array}$ & $\begin{array}{l}(0.03-0.1) \\
4.6\end{array}$ \\
\hline Mediterranean & 561 & $67(81)$ & $(11,500,000-35,500,000)$ & 1.4 & 2.3 & 0.0 & $(1.3-4.1)$ & $(2.2-6.9)$ \\
\hline
\end{tabular}


or $\leq 50$ individuals/year for a non-passerine species that is listed as 'Least Concern' on the global IUCN Red List (BirdLife International 2014). For globally 'Critically Endangered', 'Endangered', 'Vulnerable' and 'Near Threatened' species, any number of illegally killed birds was regarded as significant.

For each species reported to be known or likely to be affected by illegal killing in significant numbers, we then asked the potential primary and secondary reason(s) for illegal killing (multiple reasons were possible). The response options, based on the most important reasons for illegal killing listed in BirdLife International (2011) were: (i) "predator control", relating to illegal killing of birds of prey by gamekeepers, fish-eating birds by fish-farmers, bee-eaters by honey producers, etc.; (ii) "sport", relating to illegal killing of birds for leisure, or during legal hunting of permitted species (e.g. killing of protected species); (iii) "food", relating to illegal killing of birds for human consumption, including both for personal consumption (i.e. livelihoods) and for local or commercial trade (e.g. liming or trapping of songbirds to sell them to restaurants); (iv) "taxidermy", relating to illegal killing of birds for taxidermy collection; (v) "cage-bird", relating to illegal capture for pets and the associated trade (e.g. finches for use as cage-birds, birds of prey for falconry, birds for use as live decoys, owls and raptors for pets, etc.); and (vi) "other" (with details requested). We also asked for the potential primary and secondary types of illegal killing activities affecting the species (multiple types were possible). The response options, based on the most important types of illegality listed in BirdLife International (2011) were: (i) "protected species", relating to illegal killing of protected species (including for any of the reasons given above); (ii) "within a protected area", relating to illegal killing of birds in locations such as national parks, nature reserves or game reserves where such activities are forbidden; (iii) "outside legal open season", relating to illegal killing of game species for which open and closed seasons are set in legislation; (iv) "illegal method", relating to the use of illegal means, asking for responses to specify "poisoning" (poisons/poisoned baits targeted directly at birds), "trapping" (e.g. traps, nets, snares, lime-sticks) and "shooting" (e.g. using illegal means such as silencers, and automatic or semi-automatic guns); (v) "other" (with details requested). We also asked for a minimum and maximum approximate estimate of the total number of individuals killed illegally per year in the country, and for an explanation of how the estimate was derived. Estimates with credible wide range limits were possible, to take into account the level of uncertainty (e.g. 100-10,000 individuals), increasing the probability that the real value falls within the lower and upper limits of estimates. We also asked respondents to score confidence in each estimate, ranging from I (not at all confident) to 5 (extremely confident). We finally asked for an estimate per species of the trend in the scale of illegal killing over the last Io years, with response options of: substantial increase $(\geq 25 \%)$, moderate increase (I-24\%), stable, moderate decline ( $1-24 \%)$, substantial decline $(\geq 25 \%)$ or unknown.

For estimates varying in terms of accuracy (e.g. based on expert opinion or on actual data), we scored the "basis of estimates" to assess their validity, as follow: I if estimate was based on informed expert opinion drawing on qualitative information on illegal killing (casual observations in the field, unofficial reports, media, information from hunters, etc.) and/or typically informed by quantitative data on bird abundance within the country (e.g. from counting systematic monitoring schemes, bird ringing schemes, etc.); 2 if estimate was based on informed expert opinion drawing on a) opportunistic (rather than systematic) site-scale data on numbers of birds observed to be killed, or b) data from rehabilitation centres, police/crime records, official reports, etc.; 3 if estimate was based on informed expert opinion drawing on systematic site-based scheme data for monitoring illegal killing of birds. Estimates for each species reported to be known or likely to be affected in significant numbers in each country were scored, and the mean scores per country and per species are presented here.

For each species likely to be affected by illegal killing but in insignificant numbers, we asked for either an estimate of the total numbers of individuals killed for all such species, or estimates for each of these species individually.

Finally, we asked for information on up to 10 worst locations for illegal killing in each country, asking respondents to estimate the approximate percentage of all birds killed illegally each year in the country that are killed at each of these locations. 
The datasets for each country were then made available online for peer-review by external experts from conservation and ornithological organisations, hunting associations, and the scientific/technical bodies and/or national focal points of relevant international conventions (e.g. the Convention on Migratory Species (CMS), the African-Eurasian Migratory Waterbird Agreement (AEWA), the Memorandum of Understanding on the Conservation of Migratory Birds of Prey in Africa and Eurasia (Raptor MoU) and the Bern Convention on the conservation of European wildlife and natural habitats), with feedback, corrections, additional information or comments requested. Our aim was to ensure that the data were as accurate as possible and integrated all relevant information. Any feedback was then used by the national experts/organisations to revise the data, and these revised datasets were used in our analysis.

\section{Data analysis}

Estimated numbers of individual birds illegally killed are presented in the results, rounded appropriately to avoid spurious precision. For species known or likely to be illegally killed in insignificant numbers, we used species-specific estimates when provided, or where a single estimate was provided for the whole group of species known or likely to be killed illegally in insignificant numbers, we divided this by the number of such species.

Among the 561 native bird species that occur regularly in at least one Mediterranean country, $459(82 \%)$ have a global population estimate documented in BirdLife International (2014). For these species, we calculated the ratio between the mean estimated number of individual birds illegally killed in the region and the mean estimated global population, to indicate the relative potential impact of illegal killing on different species. Owing to broad limits in both parameters according to their uncertainty, the ranking of species is more informative than the absolute values; for the same reason, we reported the ratio rather than the percentage. Among these $56 \mathrm{I}$ bird species, 361 (64\%) have $\geq 10 \%$ of their global breeding and resident extant of occurrences (EOO) within Europe (we divided the breeding and resident EOOs calculated from BirdLife International (2015a) by global breeding and resident EOOs from BirdLife International 2014). For these 361 species, we also calculated the ratio between the mean estimated number of individual birds illegally killed and the mean European population estimates from BirdLife International (2015a). Among these 561 bird species, 165 (29\%) are waterbird species (as described by Wetlands International 2015). Using digitised boundaries for flyway populations of these species (Wetlands International 2008), we analysed the overlap between flyway population polygons and Mediterranean countries. We calculated an estimate of number of individual birds of each population illegally killed in Mediterranean countries by summing the mean estimated number of individual birds illegally killed annually in all Mediterranean countries, adjusted by the percentage of the country's land area falling inside the flyway (i.e. if $35 \%$ of the country land area fell inside the flyway, we considered $35 \%$ of the estimate of number of individual birds illegally killed for this country). We then calculated the ratio of this value to the geometric mean of the flyway population size (Wetlands International 2015; correspondence for 231 flyway populations of 114 different species). For all ratios, we calculated the best-case scenario (i.e. the ratio between the minimum estimated number of individual birds illegally killed and the maximum estimate of the global/ European/flyway population) and the worst-case scenario (i.e. the ratio between the maximum estimated number of individual birds illegally killed and the minimum estimate of the global/ European/flyway population), reported as minimum and maximum when presented in the Tables and Supplementary Material.

For sub-regional level analysis, the 26 assessed countries/territories were grouped into three different sub-regions: Albania, Bosnia and Herzegovina, Croatia, Cyprus, France, Gibraltar, Greece, Italy, Macedonia FYR, Malta, Montenegro, Portugal, Serbia, Slovenia and Spain for "Europe"; Algeria, Egypt, Libya, Morocco and Tunisia for "North Africa"; Israel, Jordan, Lebanon, Palestinian Authority Territories, Syria and Turkey for the "Middle East and Turkey" (hereafter "Middle East"). 
From the raw data, we calculated additional variables for inclusion in the analyses. Firstly, we assigned numeric values to the qualitative information on trend in the scale of illegal killing for all species likely to be significantly impacted by the illegal killing at the country level: -2 for substantial decline, -1 for moderate decline, o for stable, +1 for moderate increase and +2 for substantial increase, and calculated the mean score per country. Unknown trends were excluded, but if they comprised $\geq 50 \%$ of species-specific trends in a country, the mean trend in illegal killing for all species likely to be significantly impacted by the illegal killing was considered as unknown for the country.

We assessed in which countries illegal killing may have the greatest impact on bird populations by calculating an "impact index". For all species likely to be significantly impacted by illegal killing in each country, we used the ratio between the mean estimated number of individual birds illegally killed in the country and the mean estimated global population, and defined the mean of these values for all species as the "impact index" for the country. We also represented the importance of each potential reason for illegal killing as an "index of importance" through the following calculation. We divided the mean estimated number of birds illegally killed per species per country and per reason by the mean total estimated number of birds killed in the country, multiplied this ratio by $I$ if the reason was scored as primary for that species in that country, or by 0.5 if it was scored as secondary, and defined the sum of these values for each reason across all species in the country as the "index of importance" for the reason in the country. We used a similar approach to calculate an analogous "index of importance" for each potential type of illegality in each country. We also expressed the total estimated number of birds illegal killed in each country as a total per $\mathrm{km}^{2}$ and as a total per 100 capita of human population. The surface area and human population of each country were taken from the World Factbook (2013-2014).

\section{Results}

\section{Number of birds estimated to be illegally killed in the Mediterranean}

In total, 11-36 million individual birds were estimated to be illegally killed in the Mediterranean region each year (Table 1 ). Non-trivial numbers of birds were reported to be killed illegally in all Mediterranean countries/territories, except Gibraltar and Israel (Table 1 ). The potentially highest total numbers of individuals estimated to be known or likely to be illegally killed per year were reported in Italy (3.4-7.8 million), followed by Egypt (0.3-10.6 million) and Syria (2.9-4.9 million; Table 1, Figure 1). Expressed as a total per $\mathrm{km}^{2}$ in each country, the potential highest rates per unit area were for Malta (18-667 individual birds estimated to be known or likely to be killed illegally/year/ $\mathrm{km}^{2}$ ), Cyprus (146-351) and Lebanon (161-335; Table 1 ). Expressed as a total per 100 capita of human population in each country, the same three countries had the highest totals: Cyprus (115-277 individual birds estimated to be known or likely to be killed illegally/year/1oo persons), Lebanon (29-59) and Malta (1-51; Table I). As an aggregate measure of the overall potential impact of illegal killing on bird populations of each species, our estimated "impact index" was highest in Libya and Turkey (Figure 2). Trends in the scale of illegal killing, averaged across all species reported to be significantly impacted by illegal killing, varied across countries, with overall reported trends increasing in four countries, stable in nine, declining in four and unknown in seven (Table 1, Figure 1).

\section{Species reported to be impacted}

Among the 56I bird species assessed, 375 species (67\%) were reported to be known, or likely to be killed illegally in significant numbers each year $(73 \%$ of waterbird species, $73 \%$ of raptor species and $67 \%$ of passerine species). An additional 81 species (14\%) were reported to be known, or likely to be killed illegally in insignificant numbers. The mean percentage of species reported to be known, or likely to be killed illegally in significant numbers at national level was $24 \% \pm 13 \%$ (range: $3 \%$ to $59 \%$; Table 1 ). 


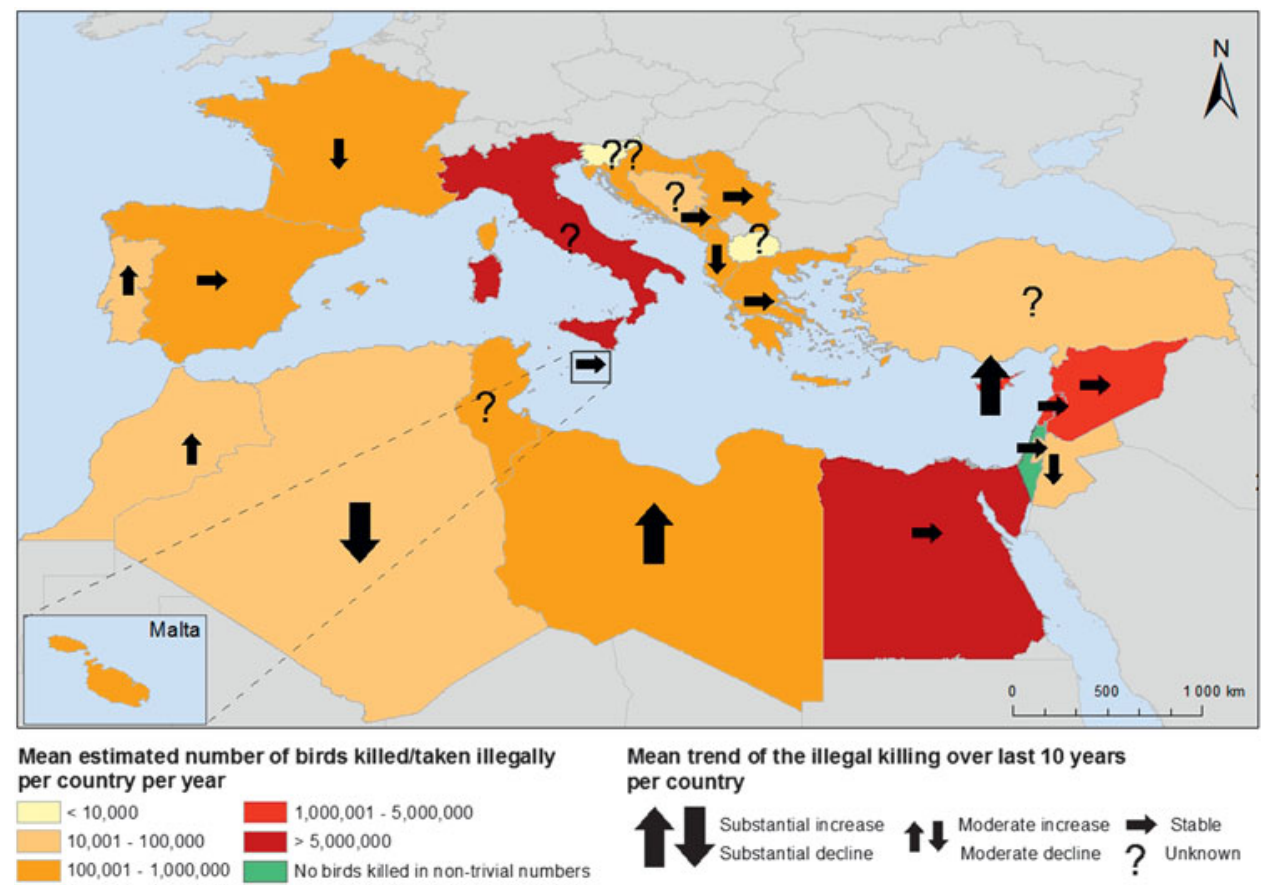

Figure 1 . Spatial pattern of illegal killing/taking of birds in the Mediterranean in terms of the mean estimated number of individual birds illegally killed/taken per year per country and the mean estimated trend in illegal killing/taking over the last 1o years. Mean estimated trends (as listed in Table 1 ) were categorised as: substantial decline (mean $<-1.5)$, moderate decline $(-1.5$ to $-0.5)$, stable (-0.4 to +0.4$)$, moderate increase $(+0.5$ to +1.5$)$ or substantial increase $(>+1.5)$.

In absolute numbers, passerines may be more impacted by illegal killing than waterbirds and raptors (Table 2). At the species level, Blackcap Sylvia atricapilla, Common Quail Coturnix coturnix, Eurasian Chaffinch Fringilla coelebs, House Sparrow Passer domesticus and Song Thrush Turdus philomelos each have a mean estimate of $>$ I million individuals illegally killed per year (Figure 3, Table 3). The results for Eurasian Chaffinch and House Sparrow were mainly driven by a high estimate reported in a single country (Table 3 ).

In terms of the impact on global populations, illegal killing may be more significant for waterbirds and raptors, compared with passerines (Table 2). At the species level, Common Shelduck Tadorna tadorna and Lesser Spotted Eagle Clanga pomarina may each have potentially $>5 \%$ of their global population illegally killed each year, these results being mainly driven by high estimates reported in a single country (Table $\mathrm{S}_{2}$ ). Of greater concern, among the 20 species with potentially the largest proportion of their global population estimated to be killed illegally per year, seven are globally threatened or 'Near Threatened', with Rock Partridge Alectoris graeca ('Near Threatened'), African Houbara Chlamydotis undulata ('Vulnerable') and White-headed Duck Oxyura leucocephala ('Endangered') among those potentially most impacted species (Table 4, Table $\mathrm{S}_{2}$ ).

In terms of the impact on European populations, Common Shelduck, White-headed Duck and Marbled Teal Marmaronetta angustirostris potentially have the largest proportion of their European population estimated to be illegally killed each year, results for the two former species being mainly driven by high estimates reported in a single country (Table $\mathrm{S}_{3}$ ). Of greater concern, among the 20 species with potentially the largest proportion of their European population estimated to be killed illegally per year, six are globally threatened or 'Near Threatened', with 


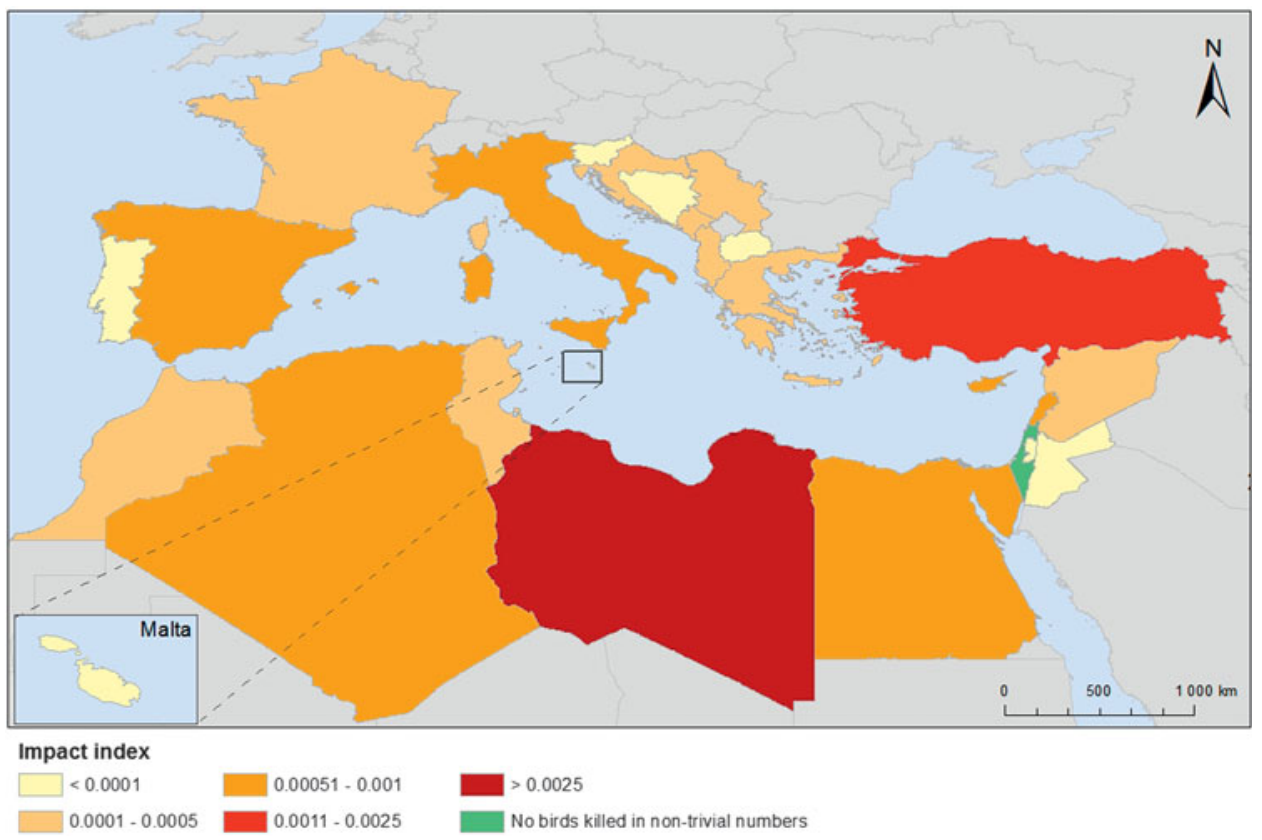

Figure 2. Spatial pattern of potential impact of illegal killing in assessed countries/territories on global populations of bird species (see methods for details).

White-headed Duck ('Endangered'), Marbled Teal ('Vulnerable') and Saker Falcon Falco cherrug ('Endangered') among those potentially most impacted species (Table 4, Table S3).

In terms of impact on flyway populations, Eurasian Curlew Numenius arquata (orientalis, Western Siberia/SW Asia E \& S Africa), Marbled Teal (East Mediterranean) and Eurasian Spoonbill Platalea leucorodia (leucorodia, Central \& SE Europe/Mediterranean \& Tropical Africa) potentially have the largest proportion of their flyway population estimated to be illegally killed each year in the Mediterranean (Table $\mathrm{S}_{4}$ ). Of the 20 species with potentially the largest proportion of their flyway population estimated to be killed illegally per year, six populations are assessed by Wetlands International (2015) to be in decline (Table S4).

\section{Worst locations reported for illegal killing of birds}

Among the 159 potential worst locations for illegal killing identified across the region by national experts (Figure 4), >100,000 individual birds were estimated to be illegally killed on average each year at 32 of these sites $(5.3-13.7$ million in total), representing $40 \%$ of the mean estimated annual regional total number of birds illegally killed for all species combined (Table $\mathrm{S}_{5}$ ). The 20 worst locations with the highest numbers of individual birds likely to be illegally killed spanned four countries: Cyprus, Egypt, Lebanon and Syria. In these 20 locations, 4.6-11.3 million individual birds were estimated to be illegally killed per year, representing $34 \%$ of the mean estimated annual regional total number of birds illegally killed for all species combined (Table 5, Figure 4).

\section{Reasons for killing and types of illegality}

Species reported to be known or likely to be illegally killed in significant numbers in the Mediterranean were reported to be targeted for sport $(82-85 \%$ of species impacted in significant 
Table 2. Estimated numbers of individual birds illegally killed/taken per year in the Mediterranean for pigeons/doves, passerines, raptors and waterbirds, and the most impacted families within these.

\begin{tabular}{|c|c|c|c|c|c|}
\hline $\begin{array}{l}\text { Group/family } \\
\text { of species }\end{array}$ & $\begin{array}{l}\text { No. species } \\
\text { in each } \\
\text { group/family }\end{array}$ & $\begin{array}{l}\text { Mean estimated no. } \\
\text { individual birds illegally } \\
\text { killed/taken per yr } \\
\text { (min - max) (millions) }\end{array}$ & $\begin{array}{l}\text { Mean ratio of estimated } \\
\text { no. birds illegally killed } \\
\text { to the global population } \\
\text { (min }-\max )\end{array}$ & $\begin{array}{l}\text { Mean score for basis of } \\
\text { estimates ( } 1=\text { informed } \\
\text { expert opinion to } \\
3=\text { extrapolated from } \\
\text { systematic monitoring) }\end{array}$ & $\begin{array}{l}\text { Mean confidence in } \\
\text { estimates ( } 1=\text { not at } \\
\text { all confident, } 5=\text { extremely } \\
\text { confident) }\end{array}$ \\
\hline Waterbirds & 165 & $1.02(0.50-1.55)$ & $0.0038(0.0017-0.0081)$ & 1.3 & 2.4 \\
\hline - Duck, geese, swans & 34 & $0.33(0.14-0.52)$ & $0.0073(0.0029-0.0131)$ & 1.4 & 2.3 \\
\hline - Rails, gallinules, coots & 9 & $0.36(0.17-0.54)$ & $0.0057(0.0023-0.0141)$ & 1.5 & 1.8 \\
\hline - Sandpipers, snipes, phalaropes & 30 & $0.18(0.10-0.26)$ & $0.0025(0.0012-0.0049)$ & 1.2 & 2.4 \\
\hline Raptors & 59 & $0.08(0.04-0.12)$ & $0.0031(0.0010-0.0076)$ & 1.6 & 2.4 \\
\hline - Hawks, eagles & 33 & $0.06(0.03-0.09)$ & $0.0099(0.0030-0.0248)$ & 1.5 & 2.2 \\
\hline Pigeons, Doves & 11 & $0.71(0.37-1.04)$ & $0.0024(0.0006-0.0088)$ & 1.3 & 2.0 \\
\hline Passerines & 237 & $19.86(9.43-30.29)$ & $0.0012(0.0004-0.0057)$ & 1.3 & 2.2 \\
\hline - Buntings & 13 & $0.30(0.17-0.43)$ & $0.0017(0.0006-0.0049)$ & 1.5 & 2.4 \\
\hline - Chats and old world flycatchers & 34 & $1.08(0.54-1.61)$ & $0.0010(0.0002-0.0038)$ & 1.5 & 2.5 \\
\hline - Crows and jays & 12 & $0.11(0.04-0.18)$ & $0.0002(0.00003-0.0011)$ & 1.5 & 2.0 \\
\hline - Finches & 25 & $4.37(2.91-5.82)$ & $0.0025(0.0008-0.0094)$ & 1.4 & 2.6 \\
\hline - Larks & 19 & $2.35(1.72-2.99)$ & $0.0015(0.0007-0.0058)$ & 1.3 & 2.5 \\
\hline - Old world warblers & 43 & $3.34(2.05-4.63)$ & $0.0023(0.0009-0.0069)$ & 1.6 & 2.7 \\
\hline - Sparrows, snowfinches and allies & 9 & $4.83(0.20-9.46)$ & $0.0048(0.0015-0.0346)$ & 1.2 & 2.5 \\
\hline - Starlings & 4 & $0.45(0.17-0.73)$ & $0.0006(0.0002-0.0012)$ & 1.4 & 1.9 \\
\hline - Thrushes & 6 & $1.76(0.92-2.60)$ & $0.0024(0.0008-0.0067)$ & 1.3 & 2.0 \\
\hline - Wagtails and pipits & 14 & $0.91(0.58-1.24)$ & $0.0018(0.0008-0.0052)$ & 1.3 & 2.6 \\
\hline Others & 89 & $1.81(1.14-2.50)$ & $0.0023(0.0008-0.0078)$ & 1.3 & 2.1 \\
\hline
\end{tabular}




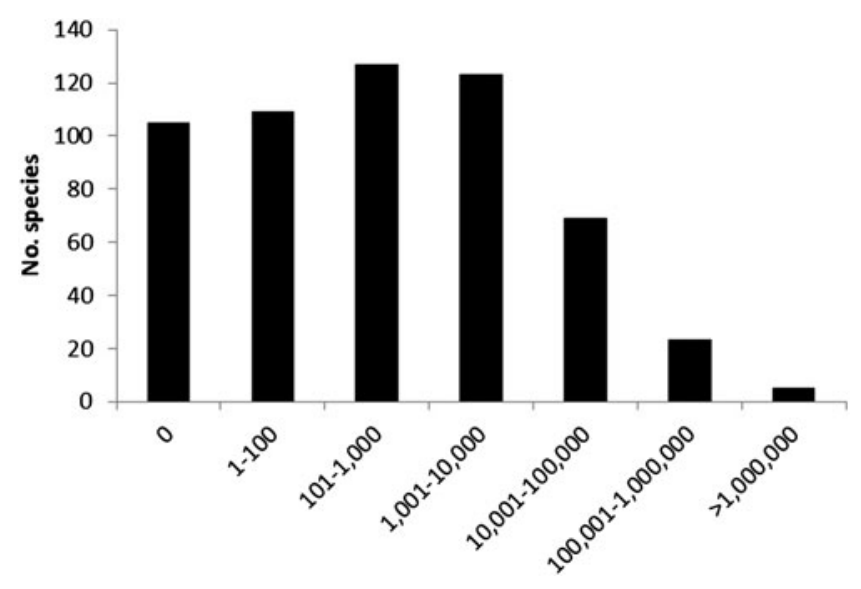

Figure 3. Mean estimated numbers of individual birds illegally killed/taken per species.

number, with the lower number being the proportion targeted for which the reason was listed as of primary importance, and the upper number including those targeted for which the reason was listed as of secondary importance), food $(65-71 \%)$ or for capture as cage-birds/decoys/etc. (29$39 \%$ ). Most species (62\%) were reported to be killed for multiple reasons, e.g. food and sport together, when birds killed for sport are then taken home and eaten (in $62 \%$ of cases where food was listed, so was sport, in $54 \%$ of cases where sport was listed, so was food). The importance of these reasons varied across the three sub-regions (Figures 5 and 6). Taxidermy and predator control were of relatively minor importance, although taxidermy may affect rare species (highly targeted for collection; e.g. in Albania, Malta and Lebanon) and predator control was listed in some European countries (e.g. France, Portugal and Spain) as the primary reason for targeting raptor species. Bird families likely to be targeted for food were mainly shrikes (six species, 100\% of species of this family present regularly in the region were reported to be illegally killed for this reason), thrushes (five species, $83 \%$ ) and ducks/geese/swans ( 28 species, $82 \%$ ). These same three bird families were also the main families targeted for sport (all six shrike species and all six thrush species, plus 32 species— $94 \%$ - of ducks/geese/swans), while those likely to be targeted for capture as cage-birds/decoys were mainly thrushes (five species, $83 \%$ ), buntings (nine species, $69 \%$ ) and shrikes (four species, $67 \%$ ); only families with more than five species were considered in this analysis).

Among the types of illegality documented, illegal shooting and illegal trapping were the most important at both the Mediterranean and subregional scales (Figures 7 and 8), with $81-84 \%$ of species known or likely to be illegally killed in significant numbers being affected by illegal shooting (with the lower number being the proportion targeted for which the type was listed as of primary importance, and the upper number including those targeted for which the type was listed as of secondary importance) and 61-70\% by illegal trapping. Bird families likely to be targeted by illegal trapping were mainly shrikes (six species, 100\% of species of this family present regularly in the region), thrushes (five species, $83 \%$ ), and rails/gallinules/coots (seven species, $78 \%$ ), while bird families likely to be targeted by illegal shooting were mainly ducks/geese/swans ( 32 species, $94 \%$ ), rails/gallinules/coots (eight species, 89\%), shrikes (five species, $83 \%$ ) and thrushes (five species, $83 \%$; only families with more than five species were considered in this analysis).

\section{Discussion}

Wildlife crime, especially illegal killing, is difficult to quantify, and its true impact on populations can be underestimated if crime is under-recorded (Amar et al. 2012). This review is the first 
Table 3. The 20 bird species with the largest estimated number of individual birds illegally killed/taken per year in the Mediterranean.

\begin{tabular}{|c|c|c|c|c|c|}
\hline Species & $\begin{array}{l}\text { Mean estimated } \\
\text { no. individual birds } \\
\text { illegally killed/year } \\
\text { (min - max) (millions) }\end{array}$ & $\begin{array}{l}\text { Mean score for basis of } \\
\text { estimates }(1=\text { informed } \\
\text { expert opinion to } \\
3=\text { extrapolated from } \\
\text { systematic monitoring) }\end{array}$ & $\begin{array}{l}\text { Mean confidence in } \\
\text { estimates ( } I=\text { not } \\
\text { at all confident, } \\
5=\text { extremely } \\
\text { confident) }\end{array}$ & $\begin{array}{l}\text { Migratory } \\
\text { status }\end{array}$ & $\begin{array}{l}\text { Countries with the largest } \\
\text { estimated no. individual } \\
\text { birds illegally killed/year }\end{array}$ \\
\hline House Sparrow Passer domesticus & $4.72(0.15-9.28)^{1}$ & 1.4 & 2.5 & Non-migrant & Egypt, Lebanon, Italy \\
\hline Eurasian Chaffinch Fringilla coelebs & $2.88(2.15-3.62)^{2}$ & 1.5 & 2.5 & Migrant & Italy, France, Lebanon \\
\hline Blackcap Sylvia atricapilla & $1.79(1.15-2.44)$ & 1.5 & 2.6 & Migrant & Syria, Lebanon, Cyprus \\
\hline Common Quail Coturnix coturnix & $1.65(1.08-2.23)$ & 1.4 & 2.6 & Migrant & Lebanon, Syria, Egypt \\
\hline Song Thrush Turdus philomelos & $1.25(0.74-1.75)$ & 1.4 & 2.3 & Migrant & Cyprus, Italy, Spain \\
\hline Calandra Lark Melanocorypha calandra & $0.95(0.70-1.20)^{3}$ & 1.3 & 2.4 & Migrant & Lebanon, Syria, Montenegro \\
\hline Eurasian Skylark Alauda arvensis & $0.75(0.51-0.98)$ & 1.3 & 2.1 & Migrant & Syria, Albania, Italy \\
\hline Meadow Pipit Anthus pratensis & $0.72(0.51-0.93)^{4}$ & 1.5 & 2.2 & Migrant & Italy, Lebanon, Syria \\
\hline European Robin Erithacus rubecula & $0.63(0.39-0.88)$ & 1.5 & 2.5 & Migrant & Italy, France, Syria \\
\hline European Turtle-dove Streptopelia turtur & $0.60(0.34-0.87)$ & 1.5 & 2.5 & Migrant & Libya, Syria, Greece \\
\hline European Goldfinch Carduelis carduelis & $0.49(0.31-0.66)$ & 1.5 & 2.8 & Migrant & Greece, Italy, Syria \\
\hline Common Starling Sturnus vulgaris & $0.45(0.17-0.73)$ & 1.3 & 2.2 & Migrant & Italy, Croatia, Lebanon \\
\hline Lesser Whitethroat Sylvia curruca & $0.42(0.23-0.62)^{5}$ & 1.5 & 2.4 & Migrant & Cyprus, Syria, Lebanon \\
\hline Common Whitethroat Sylvia communis & $0.40(0.28-0.52)^{6}$ & 1.4 & 2.3 & Migrant & Syria, Cyprus, Lebanon \\
\hline Common Chiffchaff Phylloscopus collybita & $0.36(0.18-0.54)^{7}$ & 1.4 & 2.6 & Migrant & Cyprus, Syria, Italy \\
\hline Greater Short-toed Lark Calandrella brachydactyla & $0.28(0.22-0.35)^{8}$ & 1.5 & 2.6 & Migrant & Syria, Lebanon, Greece \\
\hline Common Coot Fulica atra & $0.28(0.14-0.42)$ & 1.2 & 2.4 & Migrant & Egypt, Croatia, Turkey \\
\hline Lesser Short-toed Lark Calandrella rufescens & $0.27(0.21-0.34)^{9}$ & 1.1 & 3.0 & Migrant & Syria, Lebanon, Tunisia \\
\hline Hawfinch Coccothraustes coccothraustes & $0.26(0.10-0.41)^{10}$ & 1.6 & 2.0 & Migrant & Italy, Greece, Lebanon \\
\hline Redwing Turdus iliacus & $0.22(0.06-0.38)^{11}$ & 1.4 & 2.3 & Migrant & Italy, Syria, Spain \\
\hline
\end{tabular}

${ }^{1}$ This results is largely driven by an estimate of $50,000-9,000,000$ individuals illegally killed per year in Egypt ( $96 \%$ of the total mean estimate)

${ }^{2}$ This results is largely driven by an estimate of 2,000,000-3,000,000 individuals illegally killed per year in Italy ( $87 \%$ of the total mean estimate)

3 This results is largely driven by an estimate of 528,000-924,000 individuals illegally killed per year in Lebanon ( $76 \%$ of the total mean estimate)

4This results is largely driven by an estimate of 500,000-900,000 individuals illegally killed per year in Italy ( $97 \%$ of the total mean estimate)

5 This results is largely driven by an estimate of $179,000-537,000$ individuals illegally killed per year in Cyprus ( $85 \%$ of the total mean estimate)

${ }^{6}$ This results is largely driven by an estimate of 250,000-438,000 individuals illegally killed per year in Syria ( $86 \%$ of the total mean estimate)

7 This results is largely driven by an estimate of $155,000-465,000$ individuals illegally killed per year in Cyprus ( $86 \%$ of the total mean estimate)

${ }^{8}$ This results is largely driven by an estimate of $210,000-336,000$ individuals illegally killed per year in Syria (97\% of the total mean estimate)

9This results is largely driven by an estimate of $210,000-336,000$ individuals illegally killed per year in Syria (99\% of the total mean estimate)

${ }^{10}$ This results is largely driven by an estimate of $100,000-400,000$ individuals illegally killed per year in Italy ( $98 \%$ of the total mean estimate)

${ }^{11}$ This results is largely driven by an estimate of 50,000-300,000 individuals illegally killed per year in Italy ( $80 \%$ of the total mean estimate) 
Table 4. The 20 threatened and Near Threatened bird species with potentially the highest ratio between the estimated number of individuals killed/taken illegally per year in the Mediterranean and the global/European population size (ranked by global ratio, with ranks in brackets for European ratio). 2014 IUCN Red List category: NT = Near Threatened, VU = Vulnerable, EN = Endangered, CR = Critically Endangered.

\begin{tabular}{|c|c|c|c|c|c|c|}
\hline $\begin{array}{l}\text { Species (IUCN Red List } \\
\text { category) }\end{array}$ & $\begin{array}{l}\text { Ratio of estimated } \\
\text { no. individual birds } \\
\text { illegally killed/taken } \\
\text { to the global population } \\
\text { (min - max) }\end{array}$ & $\begin{array}{l}\text { Ratio of estimated } \\
\text { no. individual birds } \\
\text { illegally killed/taken } \\
\text { to the European } \\
\text { population (min - max) }\end{array}$ & $\begin{array}{l}\text { Mean score for basis } \\
\text { of estimates ( } 1=\text { informed } \\
\text { expert opinion to } \\
3=\text { extrapolated from } \\
\text { systematic monitoring) }\end{array}$ & $\begin{array}{l}\text { Mean confidence } \\
\text { in estimates } \\
(1=\text { not at all } \\
\text { confident, } \\
5=\text { extremely } \\
\text { confident) }\end{array}$ & $\begin{array}{l}\text { Migratory } \\
\text { status }\end{array}$ & $\begin{array}{l}\text { Countries with the } \\
\text { largest estimated no. } \\
\text { individual birds } \\
\text { illegally killed/year }\end{array}$ \\
\hline $\begin{array}{l}\text { Rock Partridge Alectoris } \\
\text { graeca (NT) } \\
\text { African Houbara Chlamydotis }\end{array}$ & $0.045(0.014-0.101)$ & 0.045 (0.014-0.101) [7] & 1.1 & 2.1 & $\begin{array}{r}\text { Altitudinal } \\
\text { Migrant }\end{array}$ & Croatia/Italy, Albania \\
\hline $\begin{array}{l}\quad \text { undulata (VU) } \\
\text { White-headed Duck Oxyura }\end{array}$ & $0.041(0.017-0.103)$ & - & 1.1 & 1.6 & Unknown & Libya, Algeria, Tunisia \\
\hline $\begin{array}{l}\text { leucocephala (EN) } \\
\text { Spanish Imperial Eagle Aquila }\end{array}$ & $0.035(0.003-0.089)^{1}$ & $0.285(0.019-0.926)[1]^{1}$ & 1.3 & 2.2 & Migrant & Turkey, Syria, Algeria \\
\hline $\begin{array}{l}\text { adalberti (VU) } \\
\text { Ferruginous Duck Aythya }\end{array}$ & $0.035(0.008-0.061)^{2}$ & $0.077(0.019-0.137)[5]^{2}$ & 2.0 & 2.0 & Non-migrant & Spain \\
\hline $\begin{array}{l}\text { nyroca }(\mathrm{NT}) \\
\text { Syrian Serin Serinus }\end{array}$ & $0.029(0.014-0.053)$ & $0.085(0.041-0.162)[4]$ & 1.3 & 2.2 & Migrant & Serbia, Libya, Croatia \\
\hline $\begin{array}{l}\text { syriacus (VU) } \\
\text { Eurasian Curlew Numenius }\end{array}$ & $0.026(0.007-0.106)^{3}$ & - & 1.3 & 2.5 & Migrant & Lebanon, Syria \\
\hline arquata $(\mathrm{NT})$ & $0.019(0.012-0.030)^{4}$ & $0.027(0.018-0.040)[10]^{4}$ & 1.2 & 2.2 & Migrant & Libya, Italy, Albania \\
\hline $\begin{array}{l}\text { Red Kite Milvus milvus (NT) } \\
\text { Sociable Lapwing Vanellus }\end{array}$ & $0.016(0.005-0.030)^{5}$ & $0.016(0.005-0.030)[11]^{5}$ & 1.5 & 1.7 & Migrant & Spain, Italy Portugal \\
\hline $\begin{array}{l}\text { gregarious (CR) } \\
\text { Marbled Teal Marmaronetta }\end{array}$ & $0.011(0.004-0.019)$ & - & 1.0 & 2.5 & Migrant & Syria, Turkey \\
\hline $\begin{array}{l}\text { angustirostris (VU) } \\
\text { Egyptian Vulture Neophron }\end{array}$ & $0.010(0.003-0.019)$ & $0.244(0.041-0.959)[2]$ & 1.1 & 2.2 & Migrant & Turkey, Syria, Tunisia \\
\hline percnopterus (EN) & $0.009(0.002-0.031)^{6}$ & - & 1.3 & 2.2 & Migrant & Spain, Turkey, Syria \\
\hline
\end{tabular}


Table 4. Continued.

\begin{tabular}{|c|c|c|c|c|c|c|}
\hline $\begin{array}{l}\text { Species (IUCN Red List } \\
\text { category) }\end{array}$ & $\begin{array}{l}\text { Ratio of estimated } \\
\text { no. individual birds } \\
\text { illegally killed/taken } \\
\text { to the global population } \\
\text { (min - max) }\end{array}$ & $\begin{array}{l}\text { Ratio of estimated } \\
\text { no. individual birds } \\
\text { illegally killed/taken } \\
\text { to the European } \\
\text { population (min - max) }\end{array}$ & $\begin{array}{l}\text { Mean score for basis } \\
\text { of estimates ( } 1=\text { informed } \\
\text { expert opinion to } \\
3=\text { extrapolated from } \\
\text { systematic monitoring) }\end{array}$ & $\begin{array}{l}\text { Mean confidence } \\
\text { in estimates } \\
\text { ( } 1=\text { not at all } \\
\text { confident, } \\
5=\text { extremely } \\
\text { confident) }\end{array}$ & $\begin{array}{l}\text { Migratory } \\
\text { status }\end{array}$ & $\begin{array}{l}\text { Countries with the } \\
\text { largest estimated no. } \\
\text { individual birds } \\
\text { illegally killed/year }\end{array}$ \\
\hline $\begin{array}{l}\text { Pallid Harrier Circus } \\
\text { macrourus (NT) }\end{array}$ & $0.008(0.004-0.015)$ & $0.045(0.017-0.151)[8]$ & 1.2 & 2.1 & Migrant & Italy, Cyprus, Turkey \\
\hline $\begin{array}{l}\text { Cinereous Vulture Aegypius } \\
\text { monachus (NT) }\end{array}$ & $0.008(0.004-0.013)^{7}$ & $0.027(0.015-0.041)[9]^{7}$ & 1.6 & 2.6 & Migrant & Spain \\
\hline $\begin{array}{l}\text { Eastern Imperial Eagle Aquila } \\
\text { heliaca (VU) }\end{array}$ & $0.006(0.001-0.028)$ & $0.013(0.004-0.026)[12]$ & 1.1 & 2.1 & Migrant & Turkey, Egypt, Syria \\
\hline $\begin{array}{l}\text { Great Bustard Otis tarda (VU) } \\
\text { Yelkouan Shearwater Puffinus } \\
\text { yelkouan (VU) }\end{array}$ & $0.006(0.002-0.012)$ & $0.006(0.002-0.010)[14]$ & 1.3 & 2.7 & Migrant & Turkey, Spain, Syria \\
\hline $\begin{array}{l}\text { Northern Bald Ibis Geronticus } \\
\text { eremita (CR) }\end{array}$ & $0.004(0.002-0.006)^{8}$ & - & 1.0 & 5.0 & Migrant & Givere, ividita \\
\hline $\begin{array}{l}\text { Caucasian Grouse Lyrurus } \\
\text { mlokosiewiczi (NT) }\end{array}$ & $0.004(0.001-0.008) 9$ & $0.005(0.001-0.014)[15]^{9}$ & 1.0 & 1.0 & Non-migrant & Turkey \\
\hline $\begin{array}{l}\text { Dalmatian Pelican Pelecanus } \\
\text { crispus (VU) } \\
\text { Bearded Vulture Gypaetus }\end{array}$ & $0.003(0.001-0.007)$ & $0.004(0.001-0.007)[16]$ & 1.2 & 3.0 & Migrant & $\begin{array}{l}\text { Greece, Albania, } \\
\text { Lebanon }\end{array}$ \\
\hline barbatus (NT) & $0.003(0.0001-0.020)$ & - & 1.5 & 2.3 & Non-migrant & Spain, France, Italy \\
\hline $\begin{array}{l}\text { Saker Falcon Falco cherrug (EN) } \\
\text { Lesser White-fronted Goose }\end{array}$ & - & $0.117(0.053-0.207)[3]$ & 1.4 & 2.3 & Migrant & $\begin{array}{l}\text { Turkey, Libya, Serbia } \\
\text { Syria, Turkey, Bosnia }\end{array}$ \\
\hline Anser erythropus (VU) & - & $0.061(0.024-0.146)[6]$ & 1.5 & 2.0 & Migrant & and Herzegovina \\
\hline $\begin{array}{l}\text { Greater Spotted Eagle Clanga } \\
\text { clanga (VU) } \\
\text { European Roller Coracias } \\
\text { garrulus (NT) }\end{array}$ & - & $0.010(0.004-0.017)[13]$ & 1.3 & 2.4 & $\begin{array}{l}\text { Migrant } \\
\text { Migrant }\end{array}$ & $\begin{array}{l}\text { Syria/Turkey, Italy } \\
\text { Syria, Cyprus, } \\
\text { Lebanon }\end{array}$ \\
\hline
\end{tabular}


Table 4. Continued.

\begin{tabular}{|c|c|c|c|c|c|c|}
\hline $\begin{array}{l}\text { Species (IUCN Red List } \\
\text { category) }\end{array}$ & $\begin{array}{l}\text { Ratio of estimated } \\
\text { no. individual birds } \\
\text { illegally killed/taken } \\
\text { to the global population } \\
\text { (min - max) }\end{array}$ & $\begin{array}{l}\text { Ratio of estimated } \\
\text { no. individual birds } \\
\text { illegally killed/taken } \\
\text { to the European } \\
\text { population (min - max) }\end{array}$ & $\begin{array}{l}\text { Mean score for basis } \\
\text { of estimates ( } 1=\text { informed } \\
\text { expert opinion to } \\
3=\text { extrapolated from } \\
\text { systematic monitoring) }\end{array}$ & $\begin{array}{l}\text { Mean confidence } \\
\text { in estimates } \\
\text { ( } 1=\text { not at all } \\
\text { confident, } \\
5=\text { extremely } \\
\text { confident) }\end{array}$ & $\begin{array}{l}\text { Migratory } \\
\text { status }\end{array}$ & $\begin{array}{l}\text { Countries with the } \\
\text { largest estimated no. } \\
\text { individual birds } \\
\text { illegally killed/year }\end{array}$ \\
\hline \multicolumn{7}{|l|}{ Semi-collared Flycatcher } \\
\hline Ficedula semitorquata (NT) & - & $0.003(0.001-0.009)[18]^{10}$ & 2.0 & 3.0 & Migrant & Cyprus \\
\hline \multicolumn{7}{|l|}{ Red-footed Falcon Falco } \\
\hline vespertinus (NT) & - & $0.002(0.001-0.004)[19]$ & 1.3 & 2.2 & Migrant & Syria, Italy, Serbia \\
\hline \multicolumn{7}{|l|}{ Black-tailed Godwit Limosa } \\
\hline $\operatorname{limosa}(\mathrm{NT})$ & - & $0.001(0.0004-0.002)[20]$ & 1.2 & 1.9 & Migrant & Albania, France, Italy \\
\hline
\end{tabular}

${ }^{1}$ This results is largely driven by an estimate of $10-610$ individuals illegally killed per year in Turkey ( $84 \%$ of the total mean estimate)

${ }^{2}$ This results is largely driven by an estimate of 20-150 individuals illegally killed per year in Spain (98\% of the total mean estimate)

3 This results is largely driven by an estimate of $80-320$ individuals illegally killed per year in Lebanon ( $84 \%$ of the total mean estimate)

4This results is largely driven by an estimate of $15,000-20,000$ individuals illegally killed per year in Libya ( $85 \%$ of the total mean estimate)

5 This results is largely driven by an estimate of 430-1,800 individuals illegally killed per year in Spain (81\% of the total mean estimate)

${ }^{6}$ This results is largely driven by an estimate of 90-500 individuals illegally killed per year in Spain (79\% of the total mean estimate)

7This results is largely driven by an estimate of 100-250 individuals illegally killed per year in Spain (89\% of the total mean estimate)

${ }^{8}$ This results is largely driven by an estimate of $1-3$ individuals illegally killed per year in Italy (100\% of the total mean estimate)

${ }_{9}$ This results is largely driven by an estimate of 100-500 individuals illegally killed per year in Turkey (100\% of the total mean estimate)

${ }^{10}$ This results is largely driven by an estimate of 50-300 individuals illegally killed per year in Cyprus (100\% of the total mean estimate) 


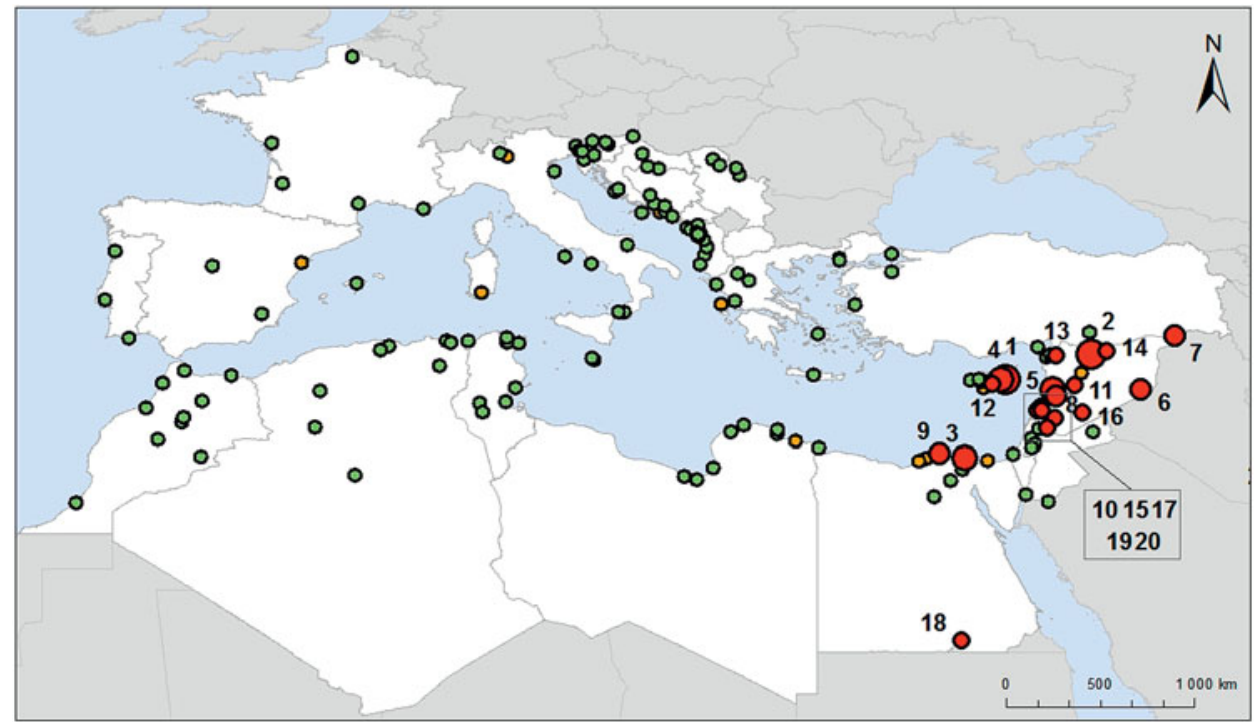

Mean estimated number of birds killed/taken illegally per location per year

- $<100,000 \quad 0>100,000 \square$ Countries assessed

The $\mathbf{2 0}$ locations at which potentially the largest number of individual birds are reported to be illegally killed/taken per year

○ $<400,000 \bigcirc 400,001-500,000 \bigcirc 500,001-600,0000>600,000$

Figure 4. The potential worst locations where large number of individual birds are reported to be illegally killed/taken per year. Numbers match those in Table 5 .

pan-Mediterranean analysis providing detailed quantitative estimates of the scope and scale of illegal killing of birds. However, illegal activities are typically difficult to detect, and systematic monitoring systems are far from comprehensive across the region. The quality of the data gathered varies, with considerable uncertainty over some estimates, and most of them are based on expert opinion and few were scored as high confidence (Table I). Global/European/flyway population data used to indicate the relative impact of illegal killing on different species also had a broad range, reflecting uncertainty. The ranking of species presented here is therefore more informative than the absolute values. The figures presented in this paper should be considered as current best estimates, which can be further refined through future work. Improved availability of systematic monitoring data on illegal killing should allow repeat assessments to improve in accuracy over time.

\section{Scale and scope of illegal killing in the Mediterranean}

Illegal killing was reported to be widespread among Mediterranean species: $67 \%$ of bird species regularly present in at least one Mediterranean country were reported to be illegally killed in significant numbers (as defined in the Methods), and 11-36 million individuals per year were estimated to be killed illegally across the region. Earlier studies (e.g. Woldhek 1979, Magnin 1991) estimated that hundreds to thousands of millions of individual birds were killed per year, but did not distinguish between legal hunting and illegal killing, and used simplistic methods (generally extrapolating from region-wide estimates of the numbers of hunters and trappers and the number of birds shot/trapped per hunter/trapper); none attempted to compile totals per species. It is possible that better law enforcement and implementation of strong legal protection, such as that provided under the EU Birds Directive, may have reduced the total numbers of birds illegally killed each year. However, numbers of migratory birds in the region have declined substantially, with one study estimating that there are 300 million fewer farmland birds in Europe today than 
Table 5. The 20 locations at which the largest estimated numbers of individual birds are killed/taken illegally each year in the Mediterranean. Location numbers correspond to those in Figure 4.

\begin{tabular}{ll}
\hline Location [country] & $\begin{array}{l}\text { Mean estimated no. individual birds } \\
\text { illegally killed/year (min }- \text { max })\end{array}$ \\
\hline 1. Famagusta area [Cyprus] & $689,000(405,000-973,000)$ \\
2. Menbej-Tishreen Dam [Syria] & $679,000(504,000-853,000)$ \\
3. Manzala [Egypt] & $593,000(33,000-1,200,000)$ \\
4. Dhekelia Eastern Sovereign Base Area [Cyprus] & $574,000(337,000-811,000)$ \\
5. Akkar (Andkit-Mounjez) [Lebanon] & $503,000(327,000-679,000)$ \\
6. Abo Hardoub [Syria] & $465,000(346,000-585,000)$ \\
7. Malkeieh [Syria] & $465,000(346,000-585,000)$ \\
8. Fakiha [Lebanon] & $438,000(285,000-592,000)$ \\
9. Burullus [Egypt] & $428,000(24,000-832,000)$ \\
10. Roum-Aytouli [Lebanon] & $361,000(235,000-487,000)$ \\
11. Jeb Al-Jarrah [Syria] & $349,000(259,000-439,000)$ \\
12. Ayios Theodoros/Maroni areas [Cyprus] & $345,000(202,000-487,000)$ \\
13. Salqeen [Syria] & $310,000(231,000-390,000)$ \\
14. Ain Eissa [Syria] & $310,000(231,000-390,000)$ \\
15. Dalboun [Lebanon] & $297,000(193,000-400,000)$ \\
16. Saikal Lake [Syria] & $252,000(187,000-317,000)$ \\
17. Qaraoun area [Lebanon] & $245,000(159,000-331,000)$ \\
18. Lake Nasser [Egypt] & $225,000(12,000-437,000)$ \\
19. Heijaneh Lake [Syria] & $213,000(158,000-268,000)$ \\
20. Tel Shehab [Syria] & $194,000(144,000-244,000)$ \\
\hline
\end{tabular}

in 1980, primarily as a result of agricultural intensification (BirdLife International 2013). It is also plausible that earlier estimates were inaccurate by up to one or two orders of magnitude.

Our data also indicated that trends over the last decade in the numbers of birds killed illegally may have increased or remained stable in 13 countries, and have declined in only four (trends were unknown in seven countries) (Figure I). Our assessment also indicated that there may be some regional differences in motivations for illegal killing. In Mediterranean Europe and the Middle East, the primary reasons for killing birds appear to be for food and sport (Figures $5 \mathrm{~b}$ and $5 \mathrm{~d}$ ). The category 'food' covers a wide range of activities and in much of the Mediterranean illegal killing of wild birds is not for subsistence food, rather, birds are killed to be eaten as a culinary delicacy, to be sold commercially as such, or part of a kill primarily made for sport might subsequently be eaten. In North Africa (Figure 5c), most illegal killing is reported to be primarily for food. Especially in the eastern part of the latter region (Egypt and Libya), wild birds may supply an important part of the income of a relatively small number of people selling shot or trapped birds in local markets (BirdLife International 2007), meat of wild birds being highly appreciated (S. Elhalawani pers. comm. 2015). Capture of birds for the cage-bird trade may be also a significant activity in the Mediterranean (Figure 5). As well as species kept for their attractive appearance or song (e.g. finches), this category also includes trapping of falcons, eagles and other raptors (and removal of their eggs) for falconry (Brouwer 2009). Smaller falcons, harriers and passerines may be also trapped for use as lures to attract the target species or to feed them (Porter 2005, BirdLife International $2015 \mathrm{~b}$ ). Further socioeconomic research is needed to understand the drivers of illegal killing in different countries within the region. Some illegal activities were reported to be taking place at high intensity, such as the illegal trapping of songbirds in Cyprus (reported to be occurring on an industrial scale; BirdLife Cyprus 2015a) or the use of hundreds of kilometres of mist-nets along the Mediterranean coast in Egypt (Emile et al. 2014). The effect of political instability should also be studied further, as it seems to have a strong impact on illegal killing, e.g. through making weapons more available, and weakening legal enforcement of hunting regulations, but also by making usual areas for illegal killing inaccessible (BirdLife International 2015b). 
a) Mediterranean region

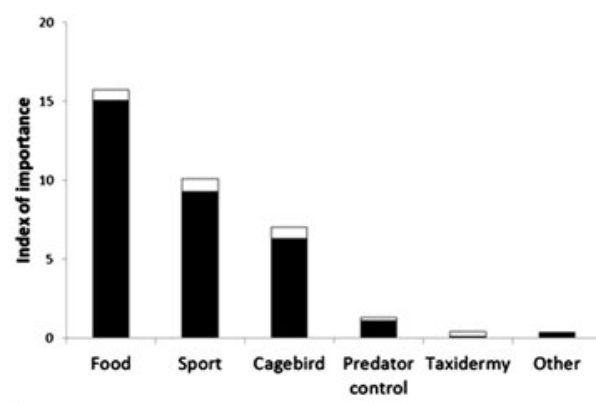

c) North African Mediterranean

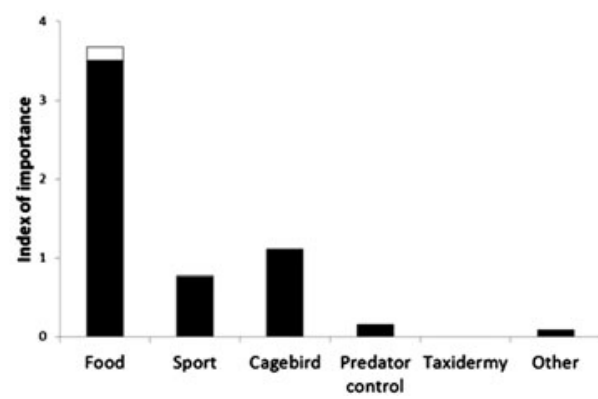

b) European Mediterranean

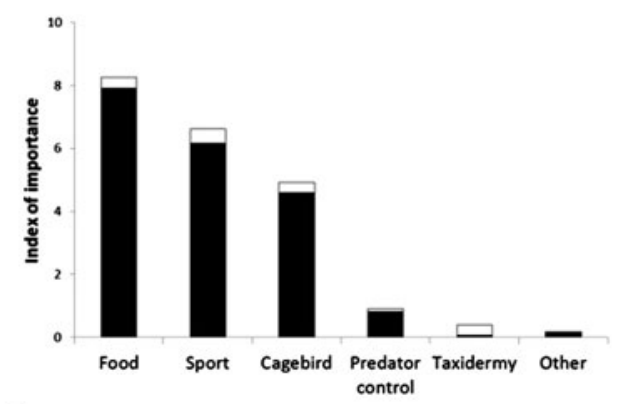

d) Middle Eastern Mediterranean

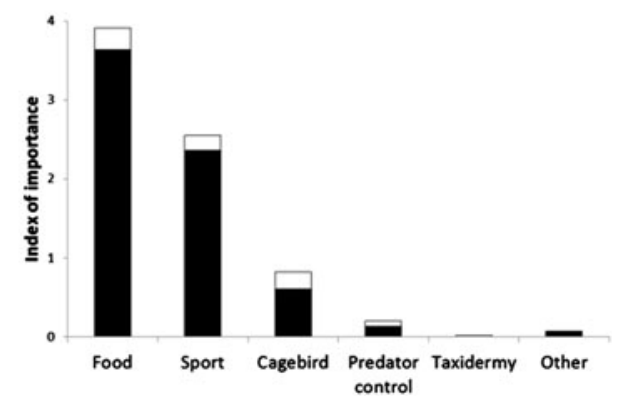

Figure 5. Index of importance of the potential reasons for illegally killing/taking birds in (a) the Mediterranean region, (b) European Mediterranean, (c) North African Mediterranean, and (d) the Middle Eastern Mediterranean. Solid bars indicate the primary reasons, open bars indicate secondary reasons (see methods for details).

A total of 32 locations across the region were identified where $>100,000$ individual birds were estimated to be killed illegally each year (Figure 4, Table $\mathrm{S}_{5}$ ). However, all of the 20 locations with potentially the largest numbers of birds reported to be illegally killed are concentrated in the Eastern Mediterranean (Figure 4, Table 5). Porter (2005) also noted that illegal shooting was the most serious threat at seven $(32 \%)$ of the 22 bottleneck sites evaluated in the Middle East and north-east Africa, including both indiscriminate shooting and trophy hunting. In the late 1980s, Cyprus had a reputation for killing more individual birds per capita than any other country in the Mediterranean (Magnin 1987) and our data indicate that this may remain the case.

\section{Impact of illegal killing on bird populations}

The demographic impact of illegal killing on bird population size is difficult to determine, especially given the uncertainty over both the estimates of the numbers of individuals killed illegally and the global/European/flyway population size. In addition, in this review we have not attempted to quantify illegal killing in the countries outside the Mediterranean region which form part of the distribution of many of these species. From that perspective any demographic impacts on species occurring both within and outside the Mediterranean region may represent underestimates. The three species for which the largest numbers of individuals were reported to be killed illegally are all listed as 'Least Concern' on the IUCN Red List (BirdLife International 2014). Of greater concern are the threatened or 'Near Threatened' species that have the highest ratios of estimated 
a)

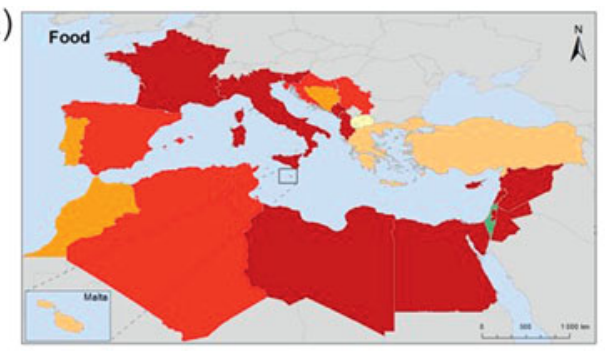

c)

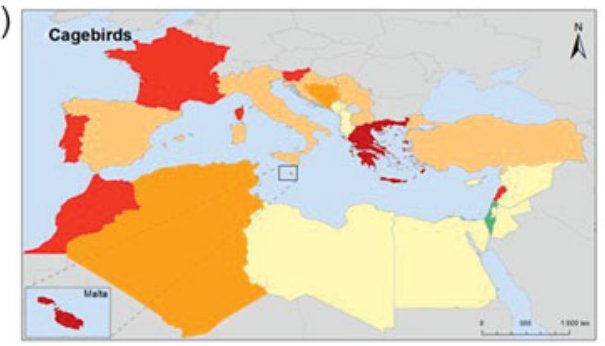

b)

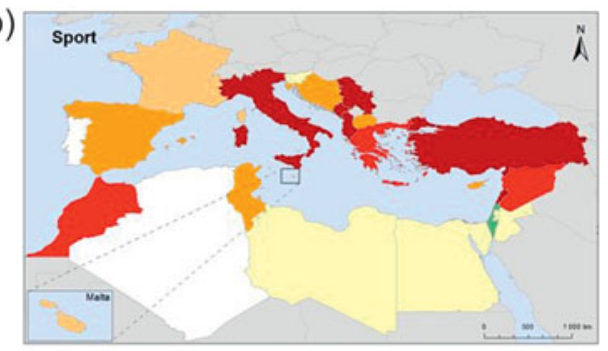

Index of importance

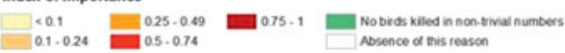
Absence $\alpha$ tris reasion

Figure 6. Spatial pattern of potential importance of the three main reasons for illegal killing/taking of birds in the Mediterranean: (a) Food, (b) Sport and (c) Cage-bird (see methods for details).

numbers of individuals killed illegally per year relative to the global or European population size (Table 4). Impacts of illegal killing have already been noted for some of these species in previous studies, for example by Azafzaf et al. (2005) for African Houbara ('Vulnerable'), Green et al. (1996) for White-headed Duck ('Endangered'), González et al. (2009) for Spanish Imperial Eagle ('Vulnerable'), Ghazal Asswad (2013) for Sociable Lapwing Vanellus gregarious ('Critically Endangered') and by Galushin et al. (2003) for Pallid Harrier ('Near Threatened').

Furthermore, it is also important to consider the impact of illegal killing at multiple scales, from local to global. For example, if a high proportion of the national or subregional population of a species migrates through a particular country, then illegally killing large numbers may have a disproportionate impact in the countries from which the birds originate. Likewise, illegal killing may cause local or even national or regional extirpations of breeding populations of species, and hence significant loss of genetic diversity. Further research is therefore needed to understand better the demographic impacts of illegal killing on bird populations in the Mediterranean region and beyond.

\section{Illegal killing and legal hunting}

Our study focused on the illegal killing of birds, but large numbers of individuals of many bird species are also hunted legally in the Mediterranean region. Because hunting legislation is not sufficiently detailed in some non-EU Mediterranean countries (e.g. permitting hunting of 'larks', 'plovers' or 'falcons', rather than individual species), hence a maximum of 152 native species may be legally hunted around the Mediterranean (BirdLife International 2015b).

Harvest information (for both legal and illegal take) is a prerequisite for assessing the sustainability of exploitation of birds. Information on hunting bag statistics is, however, in general not available and/or not up-to-date (Madsen et al. 2015). At the EU level, the only readily available data on numbers of birds legally killed are for derogations issued under the Birds Directive. This applies to four countries: France, Italy, Malta and Spain, in which 1.39 million individual birds (11,000 doves, 448,850 finches, 430,000 larks, 3,200 plovers, 200,000 starlings and 297,200 thrushes) are legally hunted each year under these derogations relating to 'traditional practices', in addition 
a) Mediterranean region

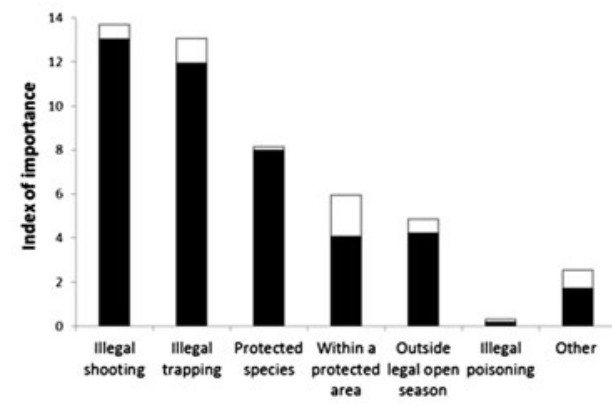

c) North African Mediterranean

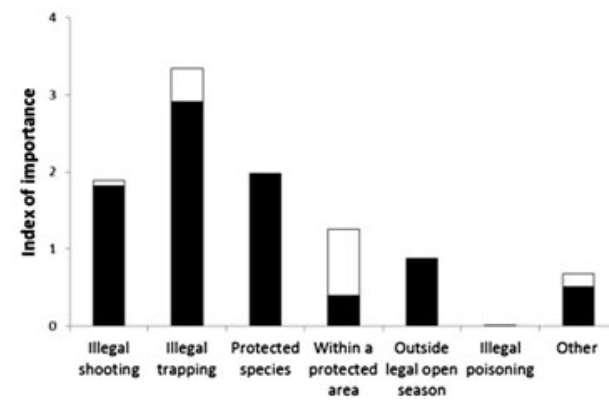

b) European Mediterranean

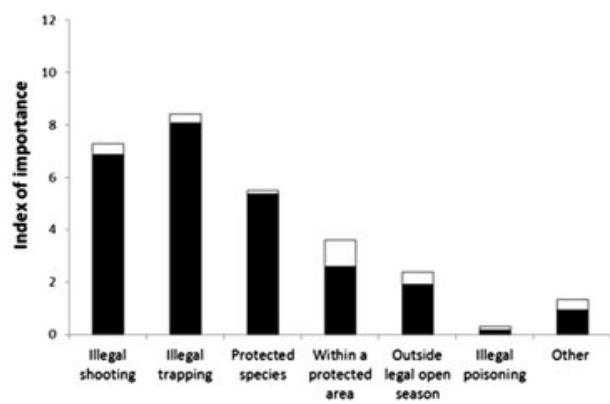

d) Middle Eastern Mediterranean

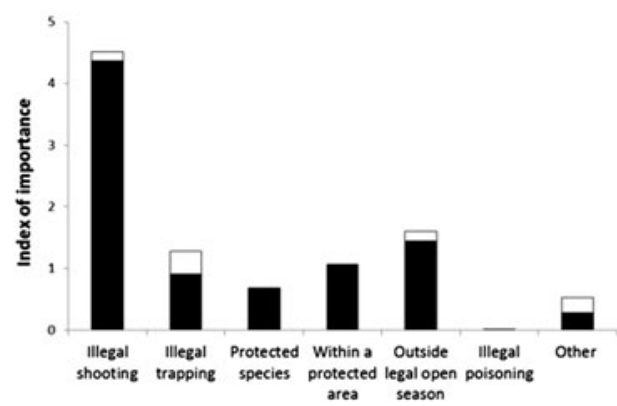

Figure 7. Index of importance of the potential types of illegality for killing/taking birds in (a) the Mediterranean region, (b) European Mediterranean, (c) North African Mediterranean, and (d) the Middle Eastern Mediterranean. Solid bars indicate the primary reason, open bars indicate secondary reasons (see methods for details).

to the 0.24-1.19 million individuals of the same species in the same countries that we estimated are killed illegally each year. For some individual species, while other threats may be important, the combined impacts of legal hunting and illegal killing may be substantial. For migratory species where the whole population passes through many countries on migration and may be subject

a)

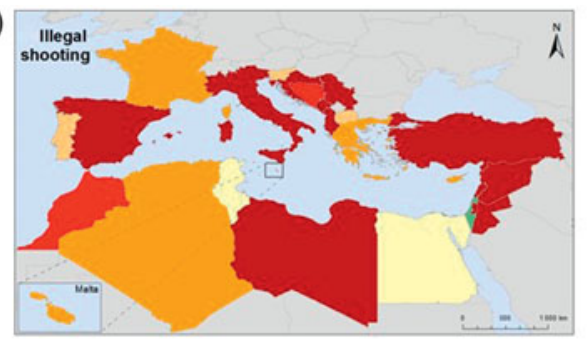

b)

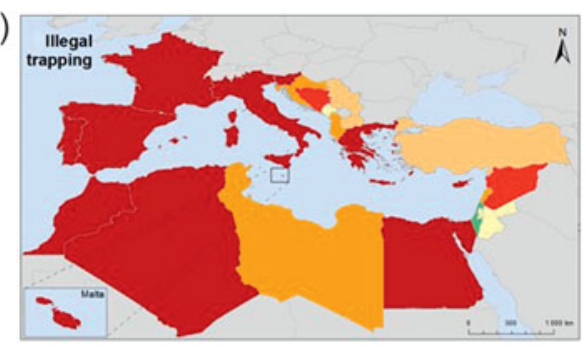

Index of importance

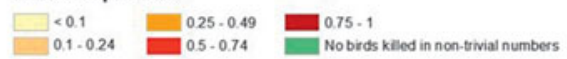

Figure 8. Spatial pattern of potential importance of the two main potential types of illegality relating to killing/taking of birds in the Mediterranean: (a) "illegal shooting" and (b) "Illegal trapping" (see methods for details). 
to mortality through illegal killing and legal hunting in each country, the assessment of cumulative mortality is therefore particularly important.

Legal hunting of many species may be within sustainable limits within the region. However data on which to base assessments of sustainability are currently largely lacking (Madsen et al. 2015). Data on mortality imposed through illegal killing as well as through legal hunting would be invaluable inputs for models used in assessing sustainability at the population level (Williams et al. 2009). Collecting, collating and synthesising such data would promote more effective management of legally hunted bird populations and facilitate the setting of sustainable national harvest limits. International policy instruments might be well-placed to facilitate the process of flyway-scale data collection, collation and analysis where no other mechanism exists. Ideally assessments of sustainability should be made at flyway scale, encompassing data from countries beyond the region to which Mediterranean species migrate. For example, in the Inner Niger Delta, 1,800-27,000 Garganey Spatula querquedula and 20,000-80,000 Ruff Calidris pugnax are estimated to be killed/taken each year (including both legal and illegal take), representing an annual loss of $1-15 \%$ and $15-60 \%$ respectively of the regional wintering populations of these two species (Zwarts et al. 2009). In the short term it will be important to prioritise assessments of sustainability of legal and illegal take for species which are of conservation concern.

\section{Monitoring and addressing the illegal killing of birds}

Our study highlighted the paucity of data on illegal killing of birds in the region, and the lack of standardised monitoring. Some countries show a strong commitment to tackling this issue and are currently collecting relevant data on illegal killing (e.g. in Albania, Greece, Italy, Jordan, Lebanon, Malta, Montenegro, Spain and Tunisia), but not as part of a systematic monitoring scheme which has the aim of generating reliable quantitative national-scale estimates of the number of birds killed per year (BirdLife International 2015b). Among the Mediterranean countries, only Cyprus is known to have an ongoing systematic monitoring scheme for illegal bird killing (BirdLife Cyprus 2015a), while Egypt is in the process of developing one (Emile et al. 2014). In Cyprus, trapping surveillance occurs in the two known worst areas for illegal trapping in Cyprus, Famagusta/Eastern Larnaca and Ayios Theodoros-Maroni area. Each spring and each autumn, teams search for evidence of illegal trapping activity in c.10o sample squares randomly selected in possible trapping areas. Monitoring is comprehensive in these areas known to have high levels of trapping activity, and trends in illegal killing can be monitored over time in these areas. Resource limitations prevent expansion of the surveillance programme to other parts of Cyprus.

Nine assessed countries are members of the EU, 22 are signatory parties of the CMS, 21 of the AEWA, I4 of the Raptor MoU and 15 of the Bern Convention, but despite the many positive impacts of recommendations of international instrument (e.g. EU legislation on bird populations; Donald et al. 2007), our data showed that illegal killing is still occurring in spite of these laws and commitments. It would be highly recommended these international policy instruments get involved in monitoring and capacity building of law enforcement at the national level where it relates to illegal killing. In particular, the EU must step up its efforts to ensure that the Birds Directive is fully enforced on the ground, rather than transposed correctly into national law and then ignored in practice. Passing new legislation setting minimum standards in environmental inspections, as well as beefing up the implementation of the environmental crimes directive would be crucial steps forward.

Illegal killing is a complex conservation problem, with key methods of killing, species targeted and motivations varying between countries. Addressing illegal killing requires action at local, national and international scales involving a variety of stakeholders, from local and national law enforcement agencies, to the judiciary, hunting groups to national government authorities, NGOs to international policy instruments. In each case it may be beneficial to develop a national action plan to agree and guide multi-stakeholder action on illegal killing, such as the ones recently implemented in Egypt and Cyprus to address the illegal trapping (Emile et al. 2014, BirdLife Cyprus 2015b). Overall, some key general areas for action would be: i) improvements to the legislation itself, ii) improving compliance with 
existing legislation, iii) improving and scaling-up enforcement of existing legislation, iv) applying consistently more effective penalties that act as a deterrent to illegal killing, v) implementing systematic monitoring of illegal killing at national scale and making results available internationally and vi) collating and analysing illegal killing monitoring data at international level and feeding it into species action planning and population modelling approaches. International policy instruments may be able to encourage and support development of national action plans and contribute to many of the key areas mentioned previously. In addition they may be able to support national stakeholders in tackling illegal killing, by promoting experience-sharing between countries facing similar issues.

\section{Conclusion}

Illegal killing of birds is a significant threat to bird species in the Mediterranean. Our preliminary assessment quantified the approximate scale and scope of this issue in the region and identified some of the species of greatest concern, and the highest priority locations at which urgent remedial action is required to tackle this issue. Our review focused geographically on the Mediterranean region, but similar data are needed in Central and Northern Europe, the Arabian Peninsula, sub-Saharan Africa and Central Asia, in order to provide a flyway-scale picture.

We carried out a preliminary baseline assessment, but it is a priority to implement systematic monitoring of illegal killing of birds and to collate and assess these data at regional and flyway level to generate more robust data, as suggested by the best practice guide for monitoring illegal killing and taking of birds (BirdLife International 2015c). The guide aims to facilitate expansion of monitoring, increase the robustness of existing and new schemes, and support the development of a more coordinated approach across the region and beyond. This would allow stakeholders to track trends, assess sustainability, target actions and monitor the effectiveness of responses. Conservation and sustainable use of bird populations in the Mediterranean require better knowledge, more effective legislation and more robust law enforcement (BirdLife International 2015b). Relevant stakeholders, including government departments and agencies, hunting groups, NGOs and international policy instruments should strengthen efforts and coordination to tackle this pressing issue for bird conservation.

\section{Supplementary Material}

The supplementary materials for this article can be found at journals.cambridge.org/bci

\section{Acknowledgements}

We are grateful to national experts and other national contributors who provided valuable national information on illegal killing, to the organisations that supported their work on this issue and to the external experts who helped to review the national data; a full list is given in the supplementary material. Thanks to Wetlands International for allowing us using flyway population delineations and flyway population estimates. Thanks to Ian Burfield, Borja Heredia, Richard Porter, Des Thompson and two anonymous referees for useful advice and comments on previous version of this paper. This review was funded by an anonymous donor to BirdLife International.

\section{References}

Amar, A., Court, I. R., Davison, M., Downing, S., Grimshaw, T. and Pickford, T. (2012) Linking nest histories, remotely sensed land use data and wildlife crime records to explore the impact of grouse moor management on peregrine falcon populations. Biol. Conserv. 145: 86-94.
Azafzaf, H., Sande, E., Evans, S. W., Smart, M. and Collar, N. J. (2005) International species action plan for the Houbara Bustard Chlamydotis undulata undulata. Nairobi, Kenya and Sandy, Bedfordshire, UK: BirdLife International and Royal Society for the Protection of Birds. 
BirdLife Cyprus (2015a) Update on illegal bird trapping activity in Cyprus. Nicosia, Cyprus: BirdLife Cyprus.

BirdLife Cyprus (2015b) Strategic action plan for tackling illegal bird trapping in Cyprus. Nicosia, Cyprus: BirdLife Cyprus.

BirdLife International (2007) Regional action plan for moving toward sustainable hunting and conservation of migratory birds in Mediterranean Third Countries. Cambridge, UK: BirdLife International.

BirdLife International (2011) Review of the illegal killing and trapping of birds in Europe. A report by the BirdLife Partnership. Cambridge, UK: BirdLife International.

BirdLife International (2013) State of the world's birds: indicators for our changing world. Cambridge, UK: BirdLife International.

BirdLife International (2014) IUCN Red List for birds. Downloaded from http://www. birdlife.org on $1 / 6 / 2014$.

BirdLife International (2015a) European Red List of birds. Luxembourg, Luxembourg: Office for Official Publications of the European Communities.

BirdLife International (2015b) Assessing the scope and scale of illegal killing and taking of birds in the Mediterranean, and establishing a basis for systematic monitoring. Cambridge, UK: BirdLife International.

BirdLife International $(2015 \mathrm{c}) \mathrm{A}$ best practice guide for monitoring illegal killing and taking of birds. Cambridge, UK: BirdLife International.

Brouwer, J. (2009) The flyway approach to conserving migratory birds. Its necessity and value. Report to UNEP/CMS, Bonn, March 2009. Bennekom, The Netherlands: Brouwer Envir. \& Agric. Consultancy.

Butchart, S. H. M. (2008) Red List Indices to measure the sustainability of species use and impacts of invasive alien species. Bird Conserv. Internatn. 18(S): 245-262.

CABS (2014) Annual report 2014. Bonn, Germany: Committee Against Bird Slaughter.

Council of Europe (2013) Convention on the Conservation of European Wildlife and Natural Habitats - Recommendation No. 164(2013) on the implementation of the Tunis Action Plan 2013-2020 for the eradication of illegal killing, trapping and trade of wild birds. Strasbourg, France: Council of Europe.
Donald, P. F., Sanderson, F. J., Burfield, I. J., Bierman, S. M., Gregory, R. D. and Waliczky, Z. (2007) International conservation policy delivers benefits for birds in Europe. Science 317: 810-813.

Emile, W., Noor, N. and Dereliev, S. (compilers) (2014) Plan of action to address bird trapping along the Mediterranean coasts of Egypt and Libya. Bonn, Germany: UNEP/ AEWA Secretariat.

European Commission (2012) Roadmap towards eliminating illegal killing, trapping and trade of birds. Brussels, Belgium: European Commission.

Franzen, J. (2010) Emptying the skies. The New Yorker 86: 48-6o.

Galushin, V., Clarke, R. and Davygora, A. (2003) International action plan for the Pallid Harrier (Circus macrourus). Strasbourg, France: Bern Convention of the Conservation of European Wildlife and Natural Habitats.

Gavin, M. C., Solomon, J. and Blank, S. G. (2010) Measuring and monitoring illegal use of natural resources. Conserv. Biol. 24: 89-100.

Ghazal Asswad, N. (2013) Surveying the Sociable Lapwing (Vanellus gregarius) in Syria and pressures it faces. Res. J. Aleppo Univ. Agri. Series 104. (In Arabic).

González, L. M., Margalida, A., Mañosa, S., Sánchez, R., Oria, J., Molina, J. I., Caldera, J., Aranda, A. and Prada, L. (2009) Causes and spatio-temporal variations of non-natural mortality in the Vulnerable Spanish Imperial Eagle Aquila adalberti during a recovery period. Oryx 41: 495-502.

Green, A. J., Fox, A. D., Hilton, G., Hugues, B., Yarar, M. and Salathé, T. (1996) Threats to Burdur Lake ecosystem, Turkey and its waterbirds, particularly the White-headed Duck. Biol. Conserv. 76: 241-252.

Kirby, J. S., Stattersfield, A. J., Butchart, S. H. M., Evans, M. I., Grimmett, R. F. A., Jones, V., O' Sullivan, J., Tucker, G. and Newton, I. (2008) Key conservation issues for migratory land- and waterbird species on the world's major flyways. Bird Conserv. Internatn. 18(S): 49-73.

Madsen, J., Guillemain, M., Nagy, S., Defos du Rau, P., Mondain-Monval, J. Y., Griffin, C., Williams, J. H., Bunnefeld, N., Czajkowski, A., 
Hearn, R., Grauer, A., Alhainen, M. and Middleton, A. (2015) Towards sustainable management of huntable migratory waterbirds in Europe. A report by the Waterbird Harvest Specialist Group of Wetlands International. Ede, The Netherlands: Wetlands International.

Magnin, G. (1987) An account of the illegal catching and shooting of birds in Cyprus during 1986. Cambridge, UK: International Council for Bird Preservation. (Study Report No. 21).

Magnin, G. (1991) Hunting and persecution of migratory birds in the Mediterranean region. Pp. 63-79 in T Salathe., ed. Conserving migratory birds. Cambridge, UK: International Council for Bird Preservation.

Mikuška, A., Horvat, D., Tomik, A. and Miskuka, T. (2014) Impact of hunting on strictly protected bird species in Croatia. $2^{\text {nd }}$ Adriatic Flyway Conference, Durres (Albania), 1-3 October.

Murgui, E. (2014) When governments support poaching: a review of the illegal trapping of thrushes Turdus spp. in the parany of Comunidad Valenciana, Spain. Bird Conserv. Internatn. 24: 127-137.

Porter, R. F. (2005) Soaring bird migration in the Middle East and North East Africa: the bottleneck sites. Report to BirdLife International for the UNDP/GEF "Migratory Soaring Birds" project.

Raine, A. F. (2007) The international impact of hunting and trapping in the Maltese Islands. Ta' Xbiex, Malta: BirdLife Malta.

Schneider-Jacoby, M. and Spangenberg, A. (2010) Bird hunting along the Adriatic Flyway - an assessment of bird hunting in Albania, Bosnia-Herzegovina, Croatia, Montenegro, Slovenia and Serbia. Pp. 32-51 in D. Denac, M. Schneider-Jacoby and B. Stumberger., eds. Adriatic Flyway - closing the gap in bird conservation. Radolfzel, Germany: EuroNatur.

St. John, F. A. V., Edwards-Jones, G., Gibbons, J. M. and Jones, J. P. G. (2010) Testing novel methods for assessing rule breaking in conservation. Biol. Conserv. 143: 1025-1030.

UNEP/CMS (2014) UNEP/CMS/Resolution 11.16 - The prevention of illegal killing, taking and trade of migratory birds. Bonn, Germany: CMS.

Vickery, J. A. Ewing, S. R., Smith, K. W., Pain, D. J., Barlein, F., Skorpilov, J. and Gregory, R. D. (2014) The decline of AfroPalaearctic migrants and an assessment of potential causes. Ibis 156: 1-22.

Wetlands International (2008) Wings Over Wetlands project. http://csntool.wingsoverwetlands.org

Wetlands International (2015) Report on the conservation status of migratory waterbirds in the Agreement area, $6^{\text {th }}$ Edition. Bonn, Germany: AEWA.

Williams, B. K., Szaro, R. C. and Shapiro, C. D. (2009) Adaptive management: The U.S. Department of the Interior technical guide. Washington, DC: Adaptive Management Working Group, U.S. Department of the Interior.

Woldhek, S. (1979) Bird killing in the Mediterranean. Zeist, The Netherlands: European Committee for the Prevention of Mass Destruction of Migratory Birds.

World Factbook (2013-2014) Washington, DC: Central Intelligence Agency. Downloaded from https://www.cia.gov/library/publications/the-world-factbook/index.html on 30/4/2015.

Zwarts, L., Bijlsma, R. G., van der Kamp, J. and Wymenga, E. (2009) Living on the edge: Wetlands and birds in a changing Sahel. Zeist, The Netherlands: KNNV publishing.

\section{ANNE-LAURE BROCHET*, VICTORIA R. JONES, RICHARD GRIMMETT, CLAIRE THOMPSON \\ BirdLife International, David Attenborough Building, Pembroke Street, Cambridge CB2 $3 Q Z, U K$.}

\section{STUART H.M. BUTCHART}

Birdlife International, David Attenborough Building, Pembroke Street, Cambridge CB2 3 QZ, $U K$ and Department of Zoology, Downing Street, Cambridge CB2 3 EJ. 
WILLEM VAN DEN BOSSCHE, ARIEL BRUNNER

BirdLife Europe and Central Asia Regional Office, Avenue de la Toison d'Or 67, 106o Brussels, Belgium.

SHARIF JBOUR

BirdLife Middle East Regional Office, Khalda, Salameh El-Ma'aaytah Street, Building No. 6, Amman, Jordan.

P. KARIUKI NDANG'ANG'A

BirdLife Africa Partnership Secretariat. P. O. Box 3502 - oo10o, Nairobi, Kenya.

WED ABDEL LATIF IBRAHIM ABDOU

Nature Conservation Sector, Egyptian Environmental Affairs Agency, 30 Misr Helwan El-Zyrae Road, Maadi, Cairo, Egypt.

ABDEL RAZZAQ AL- HMOUD

Royal Society for the Conservation of Nature (RSCN)/BirdLife Jordan, PO Box 6354, JubeihaAbu-Nusseir Circle, 11183 Amman, Jordan.

NABEGH GHAZAL ASSWAD

Syrian Society for Conservation of Wildlife (SSCW)/BirdLife Syria, Mezzeh, Damascus, Syria.

JUAN CARLOS ATIENZA, NICOLÁS LÓPEZ-JIMÉNEZ

Sociedad Española de Ornitología (SEO)/BirdLife Spain, C/Melquiades Biencinto, 34, 28053 Madrid, Spain.

IMAD ATRASH

Palestine Wildlife Society (PWLS)/BirdLife Palestine, PO Box 89, Biet Sahour, Palestinian Authority Territories.

NICHOLAS BARBARA, JUAN MULA LAGUNA, MATTEO LATTUADA, NICOLA PILUDU BirdLife Malta, 57/28, Triq Abate Rigord, Ta' Xbiex XBX 1120, Malta.

KEITH BENSUSAN

Gibraltar Ornithological and Natural History Society (GONHS)/BirdLife Gibraltar, PO Box 843, Gibraltar.

TAULANT BINO

Albanian Ornithological Society (AOS), Qendra "Don Bosko", Rr. "Don Bosko", Tirana, Albania.

CLAUDIO CELADA, MARCO GUSTIN

Lega Italiana Protezione Uccelli (LIPU)/BirdLife Italy, Via Udine 3/a, 43100 Parma, Italy.

SIDI IMAD CHERKAOUI

Groupe de Recherche pour la Protection des Oiseaux au Maroc (GREPOM)/BirdLife Morocco, Résidence Oum Hani4, Im.22, Apt.3 Salé, 11160 Morocco.

JULIETA COSTA, DOMINGOS LEITÃO, PAULA LOPES

Portuguese Society for the Study of Birds (SPEA)/BirdLife Portugal, Avenida João Crisóstomo, n 18 - 4. Dto. 100o-179 Lisboa, Portugal.

BERNARD DECEUNINCK, THIERRY MICOL, GWENAEL QUAINTENNE

Ligue pour la Protection des Oiseaux (LPO)/BirdLife France, 8 rue du Docteur Pujos, CS 90263, 17305 Rochefort cedex, France.

KHALED SALEM ETAYEB

University of Tripoli, Zoology Department, Tripoli, Libya. 
CLAUDIA FELTRUP-AZAFZAF

Association "les Amis des Oiseaux" (AAO)/BirdLife Tunisia, Avenue 18 janvier 1952, Ariana

Center, Bureau C 208/209, 2080 Ariana, Tunisia.

JERNEJ FIGELJ, PRIMOŽ KMECL

DOPPS/BirdLife Slovenia, Tržaška cesta 2, 10oo Ljubljana, Slovenia.

VLADO KOCEVSKI, KSENIJA PUTILIN

Macedonian Ecological Society (MES)/BirdLife Macedonia, ul. Vladimir Nazor 10, Skopje 1ooo, Macedonia.

MALAMO KORBETI, DANAE PORTOLOU, NIKOS TSIOPELAS, FRAN VARGAS

Hellenic Ornithological Society (HOS)/BirdLife Greece, Themistokleous str. 80, Athens, 10681, Greece.

DRAŽEN KOTROŠAN, NERMINA SARAJLI

Naše ptice, 71000 Sarajevo, Bosnia and Hercegovina.

VEDRAN LUCIĆ

BIOM association/Birdlife Croatia, Biankinijeva 12b, Zagreb, 10ooo, Croatia.

AIISSA MOALI

Laboratoire d'écologie et environnement, Université de A. Mira, Béjaïa, Algeria.

YOAV PERLMAN

Society for the Protection of Nature in Israel (SPNI)/BirdLife Israel, Hanegev 2, Tel-Aviv, 66186, Israel.

GHASSAN RAMADAN-JARADI

Society for the Protection of Nature in Lebanon (SPNL)/BirdLife Lebanon, Awad Bldg, 6th Floor Abdel Aziz Street, P.O.Box: 11-5665, Beirut, Lebanon.

MILAN RUŽIĆ

Bird Protection and Study Society of Serbia (BPSSS)/BirdLife Serbia, Radnička 20,a 21000 Novi Sad, Serbia.

ANNA SANDOR

SABUKO Society for Nature Conservation, 5 Akhmed Mealshvili Street, Batumi 6010, Georgia.

DARKO SAVELJIĆ

Center for Protection and Research of birds of Montenegro (CZIP)/BirdLife Montenegro, Piperska 370A, I ulaz, Podgorica 81000, Montenegro.

ROBERT D. SHELDON

Ornithological Society of the Middle East, Caucasus and Central Asia (OSME), clo The Lodge, Sandy, Bedfordshire SG19 2DL, UK.

TASSOS SHIALIS

BirdLife Cyprus, P.O. Box 28076, Nicosia 2090, Cyprus.

*Author for correspondence; email: anne-laure.brochet@birdlife.org

Received II July 2015; revision accepted 14 December 2015 